\title{
Evaluating the Community Land Model in a pine stand with shading manipulations and ${ }^{13} \mathrm{CO}_{2}$ labeling
}

\author{
J. Mao, D. M. Ricciuto, P. E. Thornton, J. M. Warren, A. W. King, X. Shi, C. M. Iversen, and R. J. Norby \\ Environmental Sciences Division and Climate Change Science Institute, Oak Ridge National Laboratory, \\ Oak Ridge, Tennessee, USA
}

Correspondence to: J. Mao (maoj@ornl.gov)

Received: 15 April 2015 - Published in Biogeosciences Discuss.: 7 May 2015

Revised: 30 October 2015 - Accepted: 27 December 2015 - Published: 3 February 2016

\begin{abstract}
Carbon allocation and flow through ecosystems regulates land surface-atmosphere $\mathrm{CO}_{2}$ exchange and thus is a key, albeit uncertain, component of mechanistic models. The Partitioning in Trees and Soil (PiTS) experimentmodel project tracked carbon allocation through a young $P i$ nus taeda stand following pulse labeling with ${ }^{13} \mathrm{CO}_{2}$ and two levels of shading. The field component of this project provided process-oriented data that were used to evaluate terrestrial biosphere model simulations of rapid shifts in carbon allocation and hydrological dynamics under varying environmental conditions. Here we tested the performance of the Community Land Model version 4 (CLM4) in capturing short-term carbon and water dynamics in relation to manipulative shading treatments and the timing and magnitude of carbon fluxes through various compartments of the ecosystem. When calibrated with pretreatment observations, CLM4 was capable of closely simulating stand-level biomass, transpiration, leaf-level photosynthesis, and pre-labeling ${ }^{13} \mathrm{C}$ values. Over the 3-week treatment period, CLM4 generally reproduced the impacts of shading on soil moisture changes, relative change in stem carbon, and soil $\mathrm{CO}_{2}$ efflux rate. Transpiration under moderate shading was also simulated well by the model, but even with optimization we were not able to simulate the high levels of transpiration observed in the heavy shading treatment, suggesting that the BallBerry conductance model is inadequate for these conditions. The calibrated version of CLM4 gave reasonable estimates of label concentration in phloem and in soil surface $\mathrm{CO}_{2}$ after 3 weeks of shade treatment, but it lacks the mechanisms needed to track the labeling pulse through plant tissues on shorter timescales. We developed a conceptual model for photosynthate transport based on the experimental obser-
\end{abstract}

vations, and we discussed conditions under which the hypothesized mechanisms could have an important influence on model behavior in larger-scale applications. Implications for future experimental studies are described, some of which are already being implemented in follow-on studies.

\section{Introduction}

Accurate projection of the changing global climate, given a particular scenario of future greenhouse gas emissions or concentrations, is largely determined by adequate representation of mechanistic processes in Earth system models (ESMs) (Taylor et al., 2012). Land surface models (LSMs) and their associated biogeophysical and biogeochemical parameterizations are key determinants of the ESMs' fidelity in characterizing and quantifying complex feedbacks in the Earth system (Arora et al., 2013; Friedlingstein et al., 2006; Pitman, 2003). Modeling studies have increasingly used observational data and mechanistic knowledge of processes to advance the development of LSMs (Best et al., 2011; Dai et al., 2003; Krinner et al., 2005; Oleson et al., 2013; Wang et al., 2011). Global and regional observations of land surface fluxes, states, and dynamic vegetation change offer insights into the large-scale interactions between the land surface and atmosphere and hence facilitate model improvements at relevant scales in space and time (Beer et al., 2010; Huntzinger et al., 2012; Luo et al., 2012; Randerson et al., 2009). However, to better quantify and reduce uncertainties arising from deficiencies in model process representation, parameters, driver data sets, and initial conditions, there has been significant effort to evaluate and to calibrate LSMs against site-scale ob- 
servations and experimental manipulations (Baldocchi et al., 2001; De Kauwe et al., 2014; Hanson et al., 2004; Ostle et al., 2009; Raczka et al., 2013; Richardson et al., 2012; Schaefer et al., 2012; Schwalm et al., 2010; Stoy et al., 2013; Walker et al., 2014; Williams et al., 2009; Zaehle et al., 2014). Further, model development from these focused site-scale studies, especially in close collaboration with experimentalists, can inform and prioritize new experiments and observations that are specifically designed to advance understanding of critical terrestrial ecosystems and processes (Shi et al., 2015).

The Community Land Model (CLM) is an advanced LSM with a comprehensive mechanistic parameterization of carbon (C), water, and energy budgets for diverse land types that can be applied across multiple temporal scales (Oleson et al., 2010). CLM has been evaluated against observations from a wide range of sources, and these evaluations have resulted in improved model performance (Bauerle et al., 2012; Bonan et al., 2011, 2012; Koven et al., 2013; Lawrence et al., 2011; Mao et al., 2012a, b, 2013; Oleson et al., 2008; Randerson et al., 2009; Riley et al., 2011; Shi et al., 2011, 2013, 2015; Thornton et al., 2007). Nevertheless, little attention has been paid to CLM's ability to replicate short-term manipulative experiments, which provide an avenue for exploring and validating model response to sudden, large changes in environmental drivers that control physiological and ecological responses (Amthor et al., 2001; Bonan et al., 2013; Shi et al., 2015). Processes operating over short timescales can have long-lived ecosystem consequences through indirect effects; e.g., stomatal conductance varies on timescales of hours or shorter, but indirect effects on site-level water balance through controls on transpiration can extend to annual timescales and beyond. Combined model-experiment projects can focus efforts on specific mechanistic processes whose representation in the model may be neither adequate nor appropriate for specific sites (Walker et al., 2014; Zaehle et al., 2014). Extending these model-experiment evaluations and ensuing model refinements to additional sites of the same and different ecosystem types improves confidence in the regional- and global-scale adequacy of the LSM's mechanistic process representation and parameterization.

Photosynthetic carbon (C) assimilation, the allocation of photosynthetic products into tissues with different turnover rates, and the respiration of $\mathrm{C}$ back into the atmosphere are important determinants of $\mathrm{CO}_{2}$ exchange between the terrestrial biosphere and the atmosphere (Schimel et al., 2001). Biosphere-atmosphere $\mathrm{C}$ exchange is dynamically mediated by weather, soil conditions, vegetation community composition and phenology, and natural and anthropogenic disturbances (Cannell and Dewar, 1994; Litton et al., 2007). Mechanistic characterization of the fate of photosynthetically fixed $\mathrm{C}$, in particular the magnitude and timing of $\mathrm{C}$ allocation among plant compartments, is a major challenge for experimental and modeling communities (Epron et al., 2012). Various C-allocation schemes have been proposed and implemented in LSMs to capture both the dynamic changes in
$\mathrm{C}$ allocation and response to external conditions of $\mathrm{C}$ allocation (De Kauwe et al., 2014). They generally employ either fixed coefficients or in some cases dynamic coefficients that are functions of time or time-varying external conditions to allocate assimilated $\mathrm{C}$ to different plant components (e.g., leaves, stems, and roots). These allocation schemes and coefficients are generally not well constrained by observations. More process-based understanding, better measurement techniques, and targeted experimental manipulations are needed to better constrain allocation within the model structure and the models' representations of $\mathrm{C}$ dynamics.

Carbon isotopes provide important constraints on specific processes and can be used in labeling experiments to track pulses of carbon through plant and soil components. Both diffusion through stomata and enzyme activity during photosynthesis discriminate against the accumulation of ${ }^{13} \mathrm{C}$ in plant tissue, making ${ }^{13} \mathrm{C}$ measurement a useful constraint on stomatal conductance (Farquhar et al., 1989). Exposing plants to ${ }^{13} \mathrm{C}$ enriched $\mathrm{CO}_{2}$ can provide important constraints on simulated $\mathrm{C}$ allocation (Ehleringer et al., 2000). The posttreatment carbon isotope composition $\left(\delta^{13} \mathrm{C}\right)$ of organic matter and respired $\mathrm{CO}_{2}$ can serve as a tracer of plant $\mathrm{C}$ allocation (Atkin, 2015; Bahn et al., 2012).

We evaluated the integrated response of a simulated treesoil system to an imposed alteration of shortwave radiation, the main environmental driver for photosynthesis, and compared the observed trajectory of labeled carbon pulses through that system with approximations of carbon allocation that are typical of a global-scale model. We used a version of CLM4 that has been modified to allow convenient application of the global-scale modeling algorithms at single points (PTCLM, described in Oleson et al., 2013). We evaluated the model against observations and experimental results from the "Partitioning in Trees and Soils" (PiTS) experiment established in a young loblolly pine stand in Oak Ridge, Tennessee, USA (Warren et al., 2013). The project exposed a young loblolly pine (Pinus taeda) stand to a pulse of air enriched with ${ }^{13} \mathrm{CO}_{2}$, then tracked that label from photosynthetic uptake, through the leaves, stem, and roots and ultimately out of the soil as respiratory flux (Warren et al., 2012). We addressed two questions: (i) is the model able to represent the biophysical and ecophysiological behavior of the experimental system in terms of pretreatment dynamics and stand-level response to the manipulated radiation environment? (ii) Do the biases inherent in a very simple model of storage and allocation propagate beyond the timescale of fast turnover storage pools? We hypothesized that it would be possible to parameterize the global model using site-level ecophysiological measurements and have it realistically capture the site-level influence of the shade manipulation. We further hypothesized that, in spite of missing mechanisms to track short-term storage and allocation of $\mathrm{C}$, the parameterized model could capture both pretreatment ${ }^{13} \mathrm{C}$ discrimination and post-treatment effects once the labeling pulse had traveled through the plant. 


\section{Methodology}

\subsection{Site description, experimental manipulation, and observations}

The field component of the project was conducted in a young loblolly pine stand at the University of Tennessee Forest Resources AgResearch and Education Center in Oak Ridge, Tennessee. The soil is classified as a silt-clay-loam (13.3\% sand; $35.7 \%$ clay; $51.0 \%$ silt), with bulk density ranging from 1.2 to $1.4 \mathrm{~g} \mathrm{~cm}^{-3}$ at 10 to $70 \mathrm{~cm}$ depth. One-year-old seedlings $\left(1 \mathrm{~g} \mathrm{C} \mathrm{m}^{-2}\right.$; Griffin et al., 1995) were planted at $2.5 \times 3 \mathrm{~m}$ spacing in 2003 , and the experiment was conducted in 2010 when the trees were $\sim 7 \mathrm{~m}$ tall.

In 2010, a subset of eight of the trees, adjacent to one another, and their soils were instrumented with automated sensors to continuously measure soil temperature, soil moisture vertically throughout the soil profile, soil surface ${ }^{12} \mathrm{CO}_{2}$ and ${ }^{13} \mathrm{CO}_{2}$ efflux, root production at 10 and $30 \mathrm{~cm}$ depths, stem sap flow, and stem diameter (Warren et al., 2012). Various measurements were manually collected periodically, including predawn foliar water potential, photosynthetic light- and $\mathrm{CO}_{2}$-response curves, root biomass, growth, and mortality, and soil $\mathrm{C}$ and nutrient content. Meteorological data were collected every $30 \mathrm{~min}$ at $2 \mathrm{~m}$ height in an adjacent open field and included wind speed, air temperature, photosynthetically active and shortwave radiation, precipitation, and relative humidity.

Following several weeks of pretreatment measurements, the eight study trees were enclosed with plastic film stretched over a frame surrounding the trees, and then trees were exposed to $53 \mathrm{~L}$ of 99 atom $\%{ }^{13} \mathrm{CO}_{2}$ for $45 \mathrm{~min}$. The plastic was removed and replaced with light shade (LS) or heavy shade (HS) cloth, each of which covered four trees and provided differential levels of photosynthetically active radiation (PAR) at the canopy surface for 3 weeks following the labeling. The LS and HS cloths were designed to allow passage of 70 and $10 \%$, respectively, of the incident PAR.

To assess actual conditions under the shade cloth treatments, short-term measurements of temperature, humidity, wind speed, and PAR were collected at the canopy surface following shade cloth installation. Linear regressions between meteorological data from under the shade cloth and from the open field were used to estimate conditions at the canopy surface during the experimental period. Temperature was $\sim 0.11^{\circ} \mathrm{C}\left( \pm 0.82{ }^{\circ} \mathrm{C} ; \pm 1 \mathrm{SD}\right)$ lower, relative humidity (RH) was $\sim 6 \%( \pm 5 \% ; \pm 1 \mathrm{SD})$ higher, and wind speed (u) was $\sim 45 \%( \pm 15 \%$; $\pm 1 \mathrm{SD})$ lower under both levels of shading than in the adjacent open field (Fig. 1a, b). The shade cloths performed very close to design, with 68 and $11 \%$ passage of PAR through the LS and HS cloths, respectively (Fig. 1c).

Non-destructive measurements of soil moisture, soil temperature, soil respiration, sap flow, and stem growth were made prior to the labeling and for the duration of the shade
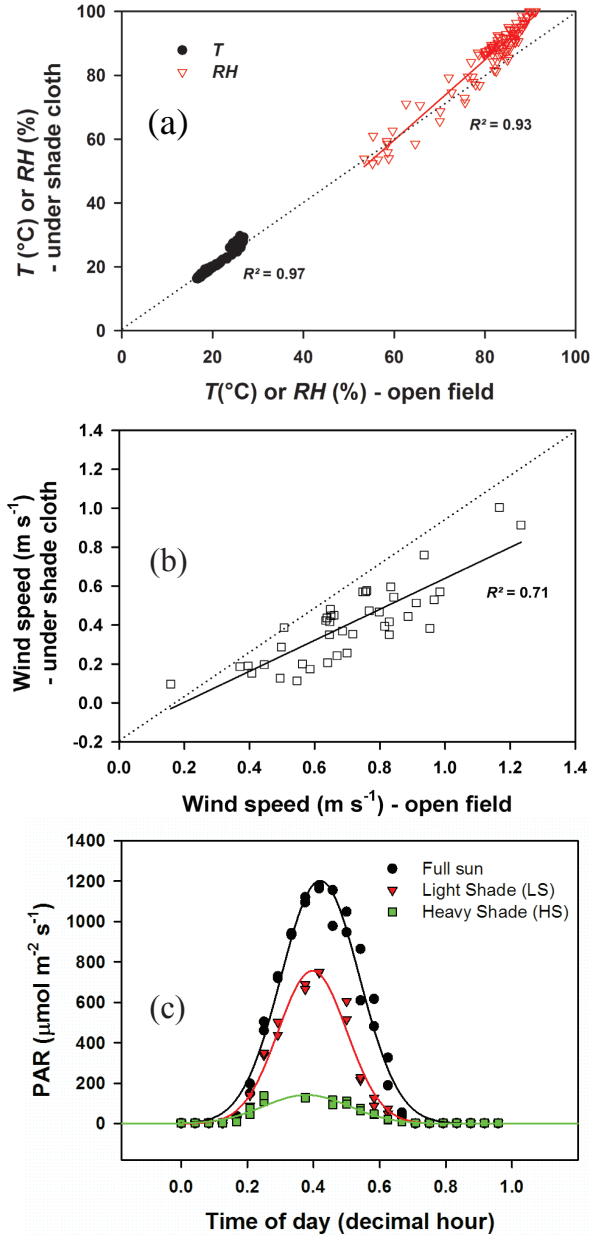

Figure 1. (a) Air temperature $\left(T,{ }^{\circ} \mathrm{C}\right)$, relative humidity $(\mathrm{RH}, \%)$, and (b) wind speed $\left(u, \mathrm{~m} \mathrm{~s}^{-1}\right)$ under the shade cloth at the top of the canopy compared with open field measurements at $2 \mathrm{~m}$ height; (c) typical diurnal patterns of photosynthetically active radiation (PAR, $\mu \mathrm{mol} \mathrm{m} \mathrm{m}^{-2} \mathrm{~s}^{-1}$ ) at the site under full sun, light shade, or heavy shade treatments.

treatment. During the shade treatment, destructive measurements of foliage, stem phloem tissue, roots, and soil were collected to assess presence of the ${ }^{13} \mathrm{C}$ label and linked to concurrent automated measurements of ${ }^{13} \mathrm{CO}_{2}$ from the soil surface (Warren et al., 2012). Experimental results and additional details on the site and experimental design are in Warren et al. (2012) and data sets are available online (Warren et al., 2013).

\subsection{Model description}

We used CLM4 (Oleson et al., 2010), the land component of the Community Earth System Model (CESM) (Gent et al., 2011), to simulate the pretreatment and manipulated processes in the PiTS study. This CLM version includes fully prognostic carbon and nitrogen representations for its vegetation, litter, and soil biogeochemistry components (Oleson et 
al., 2010, 2013; Thornton et al., 2007; Thornton and Rosenbloom, 2005).

Carbon allocation in this version of CLM is simplistic. After maintenance respiration demands are calculated and subtracted from gross primary productivity (GPP), and following a step that downregulates GPP on the basis of static allocation parameters, fixed tissue $\mathrm{C}: \mathrm{N}$ stoichiometry, and plant mineral $\mathrm{N}$ uptake, the available carbon is allocated to new growth, storage for growth in subsequent growing seasons, and associated growth respiration. The model includes pools for leaf, fine root, and several categories of stem and coarse root, with over-season storage pools associated with each of these "displayed" growth pools. The allocation ratio between stem and leaf is a function of the previous year's net primary productivity (NPP; higher fractional allocation to stem with higher annual NPP), while all other allocation ratios are fixed throughout the simulation for a given vegetation type. For ${ }^{13} \mathrm{C}$, stomatal diffusion and photosynthetic fractionation are calculated and photosynthetically fixed ${ }^{13} \mathrm{C}$ is immediately allocated to plant pools following the above description. There is no further fractionation in within-plant processes or during decomposition (Oleson et al., 2013).

Several major developments of CLM performed specifically for this study include (1) introducing the ability to represent the shade effect and experimental labeling by driving the model with observed atmospheric ${ }^{13} \mathrm{CO}_{2}$ concentrations, where before ${ }^{13} \mathrm{CO}_{2}$ was assumed to be a constant fraction of $\mathrm{CO}_{2}$; (2) developing a site-level simulation workflow that leverages PTCLM capability to reproduce actual field experiments; (3) calibrating the selected model parameters to improve predictions and reveal structural errors; and (4) adding a stand-alone testing capability for the photosynthesis subroutines.

\subsubsection{Description of PTCLM simulation}

To perform simulations at the PiTS site, we used PTCLM, a scripting framework to run site-level simulations of CLM efficiently with site-specific forcing and initialization data (Oleson et al., 2013). We performed the standard 600 years of accelerated decomposition spinup, in which soil organic matter decomposition rates are increased (Thornton and Rosenbloom, 2005), followed by 1000 years of normal spinup, in which the decomposition rates are returned to their normal values, and a transient simulation between 1850 and 2010 using historically varying $\mathrm{CO}_{2},{ }^{13} \mathrm{CO}_{2}$, nitrogen deposition, and aerosol forcing data. Long-term meteorological driver data were not available at the PiTS site and instead were taken from the nearby Walker Branch and Chestnut Ridge eddy covariance sites (Hanson et al., 2004) for the years 2000-2010. These input data were cycled continuously to drive the model through the spinup and transient simulations. On model date 1 January 2003, we simulated a harvest disturbance by removing existing vegetation biomass and simulating planting of seedlings using a biomass of $1 \mathrm{~g} \mathrm{C} \mathrm{m}^{-2}$.
The model then simulated growth of the young stand through the year 2010. For the spinup and transient phases through 2002, default temperate evergreen needleleaf model parameters were used. Beginning in 2003, model parameters were modified to simulate the planted loblolly trees, based on ecophysiological measurements and model calibration (see Sect. 2.2.2).

To simulate the treatment period, we replaced the meteorology from the eddy covariance sites with observed data at the treatment sites starting at day of ${ }^{13} \mathrm{CO}_{2}$ labeling in September 2010 (Warren et al., 2012). The ${ }^{13} \mathrm{CO}_{2}$ pulse was applied in the model (assuming $100 \%{ }^{13} \mathrm{CO}_{2}$ ) during a time matching the labeling period. Thermal infrared camera measurements under both light and heavy shade cloth made during various sky conditions indicated the need to modify the model input for incoming longwave radiation under the heavy shade treatment, by assuming that the heavy shade cloth emitted downward longwave at a blackbody temperature equal to the open field air temperature (data not shown). For the light shade case, we applied the model's internal estimate of incoming longwave radiation, which uses clear-sky assumptions about atmospheric temperature and emissivity (Idso, 1981).

\subsubsection{Model calibration for pre- and post-treatment periods}

Model evaluations are complicated by the co-occurrence of parametric and structural uncertainty, which confounds the attribution of model errors (Keenan et al., 2011). A model's performance might be negatively impacted by misrepresentation of mechanistic processes, poor parameterization of otherwise sound functional representations, or both. Parameter optimization, however, can help to isolate structural deficiencies in the model. In this study, we applied model calibration, by optimizing model parameters, as a tool to highlight areas for model development rather than simply improving predictive skill. We optimized selected CLM parameters against pretreatment data. We then evaluated the performance of the calibrated CLM in the pretreatment phase and again in the post-treatment phase without recalibration following simulation of the canopy shading and ${ }^{13} \mathrm{CO}_{2}$ treatments. Our intention is that by applying robust parameter optimization to the pretreatment simulations we will reduce parametric uncertainty (Fox et al., 2009; Ricciuto et al., 2011), leading to greater insight regarding model structural uncertainty in evaluation of the post-treatment results.

We first calibrated the model to simulate the pretreatment conditions using observations and prior information about model parameters. Data constraints for the calibration consisted of single pretreatment estimates for leaf, stem, and root biomass from allometric relationships for similarly aged loblolly pine (Baldwin and Feduccia, 1987; Naidu et al., 1998; Vanlear et al., 1986), a pretreatment $\delta^{13} \mathrm{C}$ measurement for leaves, a pretreatment $\delta^{13} \mathrm{C}$ measurement for bulk 
Table 1. Default PFT-level, site-specific, and optimized parameters for the PiTS site used in CLM 4.0. PFT-level parameters are for the temperate evergreen needleleaf forest type. Optimized values were obtained using the pretreatment data (PRE_OPT) and for the transpiration data during the shading period (HS_MB). In the HS_MB optimization, only the mp and bp parameters were optimized, while other parameters retain their pretreatment optimization values.

\begin{tabular}{|c|c|c|c|c|c|c|}
\hline Parameter & Description & Units & Default & Observed & PRE_OPT & HS_MB \\
\hline \multicolumn{7}{|l|}{ Measured } \\
\hline slatop & top of canopy specific leaf area (SLA) & $\mathrm{m}^{2}(\mathrm{~g} \mathrm{C})^{-1}$ & $1.00 \times 10^{-2}$ & $1.02 \times 10^{-2}$ & none & $1.02 \times 10^{-2}$ \\
\hline dsladlai & change in SLA through per unit LAI & $\mathrm{g} \mathrm{C}^{-1}$ & $1.25 \times 10^{-3}$ & 0 & none & 0 \\
\hline leafcn & leaf $C: N$ ratio & $\mathrm{g} \mathrm{C}\left(\mathrm{g} \mathrm{N}^{-1}\right.$ & 35 & 50 & none & 50 \\
\hline \multicolumn{7}{|l|}{ Optimized } \\
\hline $\mathrm{mp}$ & Ball-Berry stomatal conductance slope & none & 6 & none & 5.59 & 71.3 \\
\hline bp & Ball-Berry stomatal conductance intercept & $\mu \mathrm{mol} \mathrm{m}{ }^{-2} \mathrm{~s}^{-1}$ & 5000 & none & 4960 & 61100 \\
\hline froot_leaf & fine-root-to-leaf allocation ratio & none & 1 & none & 1.24 & 1.24 \\
\hline stem_leaf & stem-to-leaf allocation ratio & none & $2.2^{*}$ & none & 3.29 & 3.29 \\
\hline flnr & fraction of leaf $\mathrm{N}$ in RuBisCO & none & 0.05 & none & 0.0845 & 0.0845 \\
\hline q10_mr & maintenance respiration $t$ sensitivity & none & 1.5 & none & 2.83 & 2.83 \\
\hline
\end{tabular}

roots, and daily sap-flow and soil respiration observations from each of the 20 days preceding the ${ }^{13} \mathrm{CO}_{2}$ labeling and shading treatments. Because CLM predicts canopy transpiration but not sap flow, daily transpiration during the experiment was estimated by scaling the sap-flow measurements using sapwood area and ground area covered by the rooting system (Wullschleger et al., 2001; Warren et al., 2011). Here we assume the rooting system of each tree occupied $7.5 \mathrm{~m}^{2}$ of ground area based on the spacing between the trees. For consistency, sap flow is hereafter called transpiration for both the observational and modeled results.

Some model parameters were measured directly from observations (Table 1). Other parameters for which direct estimation was not possible were optimized to maximize fit between model results and the observed calibration data (Table 1). The selection of parameters for optimization was based on formal sensitivity analysis (Sargsyan et al., 2013) and prior experience with the model. We defined the sum of squared errors between simulation and observations weighted by data uncertainty as the cost function for the optimization. We used a genetic algorithm (Runarsson and Yao, 2000) to find a set of parameters that minimizes the cost function. Simulations were performed in parallel using two populations of 32 ensemble members in parallel over 100 iterations for a total of 6400 model simulations.

For the pretreatment (pre-labeling) period, we compared the standard "parameter" version of the model (PRE-STD) with the optimized "parameter" version (PRE-OPT). The model with optimized parameters was used in simulations for the shading treatment period for both the high shade and low shade treatments. Because of uncertainties associated with simulated stomatal conductance and transpiration in high shade conditions, we performed additional parameter calibrations for the parameters mp (slope of the Ball-
Berry stomatal conductance formulation) and bp (intercept of the Ball-Berry stomatal conductance formulation) during the shade treatment period using the genetic algorithm with transpiration and stem growth data as constraints (HS_MB), with results discussed below.

\subsubsection{Evaluation of CLM photosynthesis functions}

Since we are interested in understanding the fate of photosynthetically fixed carbon as it is allocated to various tissues and fluxes, and how allocation dynamics respond to changes in photosynthesis as driven by changes in PAR, it is useful to evaluate model predictions of photosynthesis over a range of light levels. We used a functional unit testing framework (Wang et al., 2014) to evaluate CLM's representation of the photosynthetic light response at the scale of individual leaves against light-response curves obtained by Warren et al. (2012) for foliage in the upper canopy of trees at the PiTS experimental site prior to the shade treatment. This approach isolates the targeted model process to allow a direct comparison between instrumental data and simulation output, driving the model component with specified environmental conditions and parameter values.

\section{Results}

\subsection{Environmental forcing conditions}

Mean surface air temperature adjacent to the site decreased from days -20 to 4 (day numbering is negative prior to the addition of ${ }^{13} \mathrm{CO}_{2}$ and shading treatments), then recovered somewhat and remained without obvious trend for the rest of the post-labeling period (days 5 to 25). Multiple rainfall events were recorded in the pre-treatment and treatment pe- 
riods (Fig. 2a). The shortwave and longwave radiation drivers for our simulations, based on a combination of observations and estimation as described above, showed variance associated with weather patterns during the experiment, with the superimposed influence of the light and heavy shading treatments (Fig. 2b). ${ }^{13} \mathrm{CO}_{2}$ concentrations followed historical background values except during the labeling period on day 0 (Fig. 2b).

\subsection{Pretreatment and treatment evaluation}

The model predicted approximately exponential growth in all biomass pools during the 8 years of pretreatment simulation, with some evidence of slowing growth in the final years (Fig. 3a). Using default global-scale ecophysiological parameters, the model significantly overestimated biomass accumulation in leaf, stem, and root pools, by 85,36 , and $76 \%$, respectively, on 1 September 2010 (PRE_STD curves, Fig. 3a). Replacing default parameters with observed (lower) leaf $\mathrm{N}$ concentration and with calibrated (higher) allocation ratios for stem : leaf and root: leaf (complete set of parameter changes shown in Table 2) brought the biomass accumulation curves in better agreement with observations (Fig. 3a). Using the PRE_OPT parameters, the bias for leaf, stem, and root biomass accumulations was $-9,-4$, and $-16 \%$, respectively, compared to observed values.

Comparison of predicted vs. observed photosynthesis light-response curves was used as an independent assessment of the model performance before and after calibration across a range of PAR values characteristic of midday values in the open field and under the LS and HS treatments (Fig. 3b). In the range of PAR from 750 to $1588 \mu \mathrm{mol} \mathrm{m} \mathrm{m}^{-2} \mathrm{~s}^{-1}$, typical of midday conditions in the pre-treatment period (days -25 to -1 ), default parameterization (PRE_STD) resulted in overestimates of photosynthesis, while data-constrained and calibrated parameterization (PRE_OPT) eliminated the bias, placing predictions within \pm 1 SD of observed values. For light conditions characteristic of midday values in the LS treatment $\left(648 \pm 232 \mu \mathrm{mol} \mathrm{m}^{-2} \mathrm{~s}^{-1}\right)$ the overprediction bias for the optimized model was reduced, but at PAR $=500 \mu \mathrm{mol} \mathrm{m}^{-2} \mathrm{~s}^{-1}$ the optimized-model-predicted photosynthesis was still biased high. For the range of PAR characteristic of the HS treatment $\left(131 \pm 47 \mu \mathrm{mol} \mathrm{m}^{-2} \mathrm{~s}^{-1}\right)$ the model with optimized parameters underestimated photosynthesis, while the model with default parameters was in good agreement (low end of the range) or was biased high (high end of the HS range).

Soil temperature predicted by the optimized model at 0 $5 \mathrm{~cm}$ depth had a consistent overestimation bias of $1-2^{\circ} \mathrm{C}$, but the model closely reproduced the daily variation and decreasing tendency in near-surface soil temperature in both the pretreatment and post-treatment periods (Fig. 4a). No clear influence of shading treatments on soil temperature was seen in either the observations or model simulations. Substantial variability in observed soil moisture (integrated for

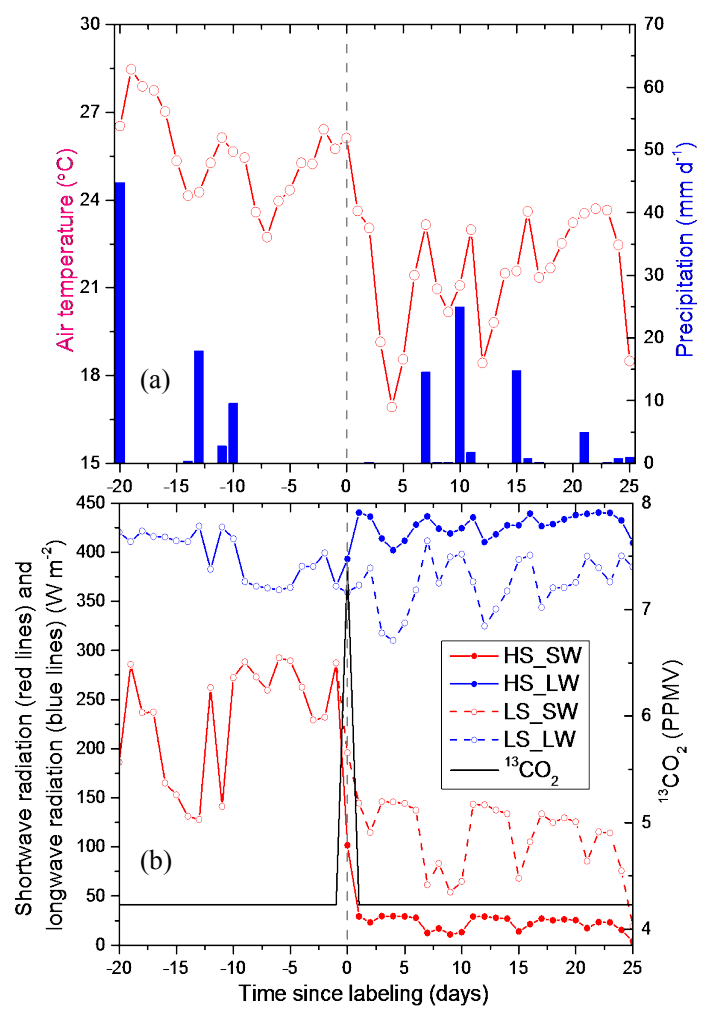

Figure 2. (a) Daily air temperature $\left({ }^{\circ} \mathrm{C}\right)$ and precipitation $\left(\mathrm{mm} \mathrm{d}^{-1}\right)$ for the pretreatment and treatment of light shade (LS) and heavy shade (HS) (day -20 to 25); (b) change in daily atmospheric longwave radiation ( $\mathrm{LW} ; \mathrm{W} \mathrm{m}^{-2}$ ), shortwave radiation $\left(\mathrm{SW} ; \mathrm{W} \mathrm{m}^{-2}\right.$ ), and ${ }^{13} \mathrm{CO}_{2}$ (PPMV) prior to and after exposure to shade treatments. Dashed gray line represents the starting day of the treatment.

$15-95 \mathrm{~cm}$ depth) was found among samples taken near different trees under the same shading treatment (Fig. 4b). Pretreatment observations of soil water content were not made, but observed LS soil water was lower than that of the HS soil water at the start of the treatment period, perhaps reflecting local differences in soil properties and pretreatment evapotranspiration. Although modeled soil water content at the start of the treatment was higher than observed (by 5$7 \%$, measured as volume $\%$ of water in soil), the maximum observed and simulated excursions in soil water content between rain events during the treatment period were similar (4 and $3.5 \%$, respectively). Predicted soil water content declined more slowly than observed during days $16-25$. There is some evidence of both observed and predicted LS water content declining more rapidly than HS in this same period, suggesting higher rates of evaporation for LS than HS.

Observed transpiration during the pretreatment period was higher for HS than LS plots, likely a consequence of the higher biomass and leaf area of the HS trees (Warren et al., 2012) and perhaps also higher soil water content (Fig. 4b). We used the pretreatment transpiration data to calibrate CLM, and the model simulated the pretreatment observa- 

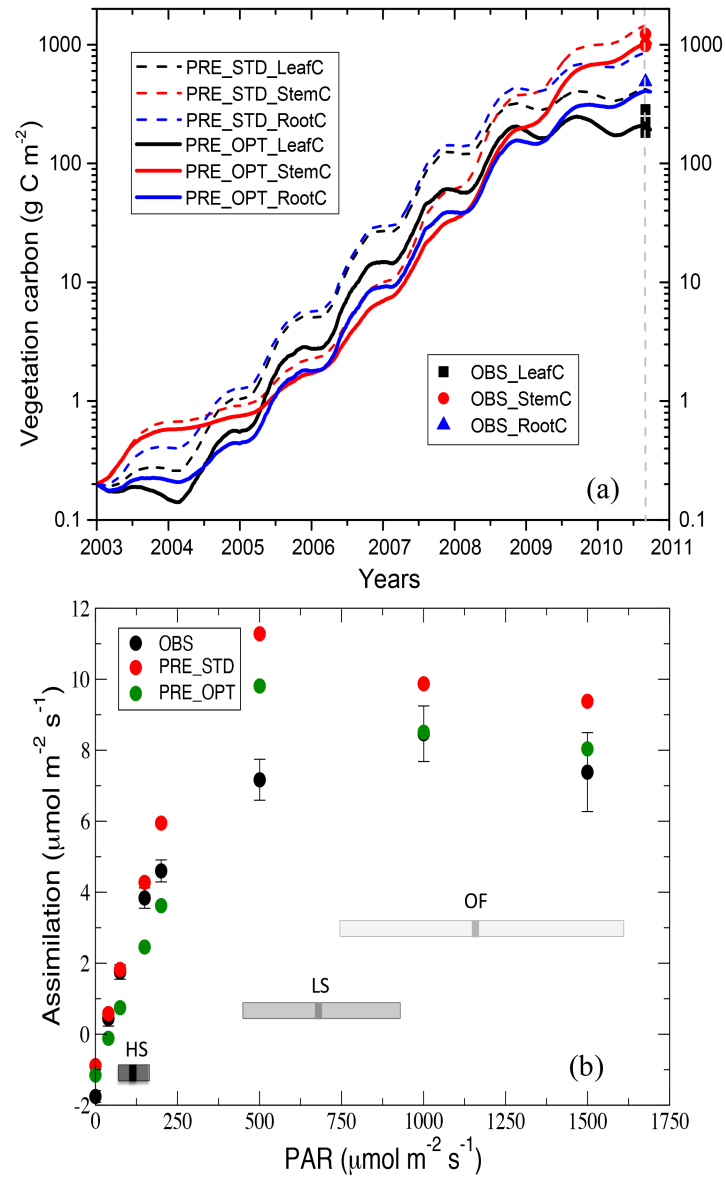

Figure 3. (a) CLM simulated change of leaf carbon (PRE_STD_LeafC), stem carbon (PRE_STD_StemC), and root carbon (PRE_STD_RootC) with default parameters and change of those (PRE_OPT_LeafC, PRE_OPT_StemC, and PRE_OPT_RootC) simulated with optimized parameters for the pretreatment period between year 2003 and 1 September 2010 (dashed gray line). Observational estimations of leaf (OBS_LeafC; 221.1, 283.8, and $181.9 \mathrm{~g} \mathrm{C} \mathrm{m}^{-2}$ ), stem (OBS_StemC; 1011.2, 973.8, and $1220.1 \mathrm{~g} \mathrm{C} \mathrm{m}^{-2}$ ), and root (OBS_RootC; $488.4 \mathrm{~g} \mathrm{C} \mathrm{m}^{-2}$ ) are based on measured stem diameters at breast height and allometric relationships from similarly aged loblolly pine (Baldwin and Feduccia, 1987; Naidu et al., 1998; Vanlear et al., 1986). Note that $y$ axis is log-10 scaled. (b) Comparison of observed and simulated light response of top of the canopy leaves of loblolly pine at the PiTS-1 site. Solid black circles are mean \pm 1 SD of observations. Solid red and green circles are simulated results from the net photosynthesis module of the functional unit testing framework using site-observed parameters (PRE_STD) and optimized parameters (PRE_OPT), respectively (see Sect. 2.2.2). Simulations are with the mean observed internal $\mathrm{CO}_{2}$ concentrations and leaf temperatures at the observed light (PAR) levels and the site's observed leaf nitrogen. Three gray bars represent the mean $\pm 1 \mathrm{SD}$ of midday PAR levels under the light shade treatment, heavy shade treatment, and open field condition. tions well in terms of both magnitude and temporal variations (Fig. 4c). After the treatment initiation, decreased transpiration was seen in both observations and model simulations for the HS and LS trees. For the LS case, CLM captured the observed transpiration well. However in the HS case, CLM predicted a sharp reduction in transpiration, whereas the observations differed relatively little from the LS case. To investigate this difference further, we performed a second optimization for the Ball-Berry stomatal conductance slope and intercept terms (HS_MB). However, despite increasing these parameters to near the maximum acceptable values (Table 1), the HS_MB optimization failed to reproduce the measured transpiration.

Both HS and LS trees showed increasing trend in stem carbon during the pretreatment period, as inferred from stem thickness measurements. While the LS stems continued to grow during the treatment period, the observed HS stem size declined (Fig. 5a). Modeled relative increase in stem carbon was more rapid during the pretreatment period than observed; additionally, while the modeled LS trees continued to accumulate carbon during the treatment period (at a somewhat reduced rate), the modeled HS tree growth essentially stopped. The observed shorter-term (3-5 day) variation in stem carbon (based on diameter change) under shading (Fig. 5a) was attributed primarily to precipitation events and changing soil moisture (Figs. $2 \mathrm{a}$ and $4 \mathrm{~b}$ ) and the accompanying swelling and shrinkage of stem diameter, which translates through the allometric functions to apparent changes in stem biomass. Apart from whole-plant mortality and fire, the model has no physiological mechanisms allowing for negative growth of stems.

Both observed and simulated soil respiration tended to decline over the study period (after day -10 in the observations) (Fig. 5b). The observed pretreatment soil respiration beneath the trees chosen for the HS treatment was $30 \%$ higher than under those selected for the LS treatment. After the application of the shade treatments, relative differences between the observed HS and LS soil respiration were reduced, but respiration from HS soil remained higher. In contrast, simulated soil respiration was slightly higher under LS, although the difference is quite small. The observed short-term variability in soil respiration under both HS and LS was not well simulated. While observations showed a reduced soil respiration coinciding with large precipitation events around days $-10,+10$, and +15 , simulated soil respiration rose on those days.

\section{3 ${ }^{13}$ C evaluation}

Observations of foliar $\delta^{13} \mathrm{C}$ show that LS and HS leaves acquired a similar concentration of labeled $\mathrm{C}$, as intended by the experimental design (Fig. 6a). Observed appearance of the labeled $\mathrm{C}$ in phloem shows that photosynthate was rapidly moved out of leaves and into phloem, with peak observed phloem concentrations on day 2 for both LS and HS 
Table 2. Pretreatment state variables included in the optimization. Simulated values were obtained using the default parameters (PRE_STD) and the optimized parameters (PRE_OPT). The bias reduction (\%) caused by the optimization is listed in the last column. In the case of leaf, root, and aboveground biomass, we use allometric equations from multiple sources (Baldwin and Feduccia, 1987; Naidu et al., 1998; Vanlear et al., 1986) that went into producing a range. The bias calculation uses the mean of the range. For sap flow and soil respiration, daily observations were made, but the values represent a mean over the 25 pretreatment days over both LS and HS periods. $\delta^{13} \mathrm{C}$ values represent observed and simulated values on the day before treatments began.

\begin{tabular}{llrrrr}
\hline State variable & Units & Observed & PRE_STD & PRE_OPT & Bias reduction (\%) \\
\hline Leaf carbon & $\mathrm{g} \mathrm{C} \mathrm{m}^{-2}$ & {$[182,221]$} & 419 & 209 & 96.55 \\
Stem carbon & $\mathrm{g} \mathrm{C} \mathrm{m}^{-2}$ & {$[973,1220]$} & 1455 & 1027 & 88.49 \\
Root carbon & $\mathrm{g} \mathrm{C} \mathrm{m}^{-2}$ & 488 & 859 & 408 & 78.44 \\
Aboveground biomass & $\mathrm{g} \mathrm{C} \mathrm{m}^{-3}$ & {$[728,1758]$} & 1645 & 1236 & 98.26 \\
$\delta^{13} \mathrm{C}$ leaf & $\% o$ & -27.99 & -27.38 & -27.49 & 18.03 \\
$\delta^{13} \mathrm{C}$ phloem & $\% o$ & -28.48 & -27.38 & -27.50 & 10.91 \\
$\delta^{13} \mathrm{C}$ Root & $\% o$ & -28.86 & -27.36 & -27.39 & 2.13 \\
Sap flow & $\mathrm{mm} \mathrm{day}^{-1}$ & 2.40 & 3.70 & 2.37 & 97.85 \\
Soil respiration & $\mu \mathrm{mol} \mathrm{m}^{-2} \mathrm{~s}^{-1}$ & 3.63 & 5.20 & 3.26 & 76.58 \\
\hline
\end{tabular}

trees (Fig. 6b). Labeled $\mathrm{C}$ was observed in $\mathrm{CO}_{2}$ at the soil surface, with peak concentrations around day 4 indicating a transfer through phloem to roots and metabolism belowground either as root respiration or as heterotrophic respiration of root exudate or root tissue (Fig. 6d). An increase in labeled $\mathrm{C}$ was observed in root tissue for both LS and HS trees, with large variability in measurements (Fig. 6c). Leaf, phloem, and root tissues showed remaining labeled $\mathrm{C}$ at day 20, and the label was still evident in soil surface $\mathrm{CO}_{2}$ at day 15. For both phloem and soil surface $\mathrm{CO}_{2}$, the $\mathrm{LS}$ plots showed lower label concentrations than the HS plots throughout the observed rise and fall of the labeled pulse. Differences between label dynamics for LS and HS roots are difficult to assess due to variability in measurements.

The model reproduced observed pretreatment values for foliar, phloem, and root tissue $\delta^{13} \mathrm{C}$ and for $\delta^{13} \mathrm{C}$ in soil $\mathrm{CO}_{2}$ flux to within $1.5 \%$ (Fig. 6), indicating reasonable model parameterizations for ${ }^{13} \mathrm{C}$ discrimination through the stomatal conductance and photosynthesis pathways. The model allocation approach deploys new photosynthate immediately throughout the plant to meet current maintenance and growth respiration demands. The belowground component of the modeled autotrophic respiration is seen as a large spike in labeled $\mathrm{C}$ in soil surface $\mathrm{CO}_{2}$ on day 0 . Other similar spikes were simulated in association with respiration of aboveground plant parts (results not shown). Lacking a representation for multi-day transport of photosynthate to sites of growth, either acropetally towards new canopy growth or basipetally towards stem or root growth, the model allocates labeled C to new growth pools immediately, where it is considered well-mixed with the existing plant tissues. There was thus a rapid increase and then a relative stabilization of the $\delta^{13} \mathrm{C}$ label in foliage and root tissue. The model does include storage pools, which hold photosynthate for deployment as new growth in following growing seasons. Those pools were lumped for comparison to the phloem observations (Fig. 6b), and they followed a pattern similar to the predicted leaf and root tissue pools.

The model predicted a steady dilution of labeled $\mathrm{C}$ in leaf, root, and storage pools for the LS trees, compared to their HS counterparts. With a severe reduction in PAR, GPP was greatly reduced in the modeled HS treatment, and what little photosynthate produced was prioritized for maintenance respiration, so the label appeared quickly in tissues and remained relatively constant for that treatment. For the LS treatment GPP remained relatively high following the labeling and initiation of the shade treatment. In this case unlabeled $\mathrm{C}$ continued to accumulate as new growth, causing a steady decline in the label concentration for LS trees over the course of the experimental period (Fig. 6a, b, c, insets). In contrast to the plant pools, modeled soil surface $\mathrm{CO}_{2}$ shows a gradual increase in label concentration after the initial root respiration pulse on day 0 , with HS consistently showing a higher concentration of label than LS for the simulated soil surface $\mathrm{CO}_{2}$ through the end of the treatment period (Fig. 6d, inset). The modeled process of leaf and fine-root litterfall is continuous throughout the year for evergreen vegetation, and this modeled rise in soil surface $\mathrm{CO}_{2}$ concentration of labeled $\mathrm{C}$ is due to litterfall and subsequent metabolism by heterotrophs.

Toward the end of the experimental period, the observed multi-day pulses of labeled $\mathrm{C}$ in phloem and soil surface $\mathrm{CO}_{2}$ approached the relatively stable values predicted by the model. The observed trajectory for label concentration in leaves fell below modeled values for the final 10 days of treatment. Variation in observed root label concentration toward the end of the experiment makes it difficult to assess correspondence with model results for that tissue. 

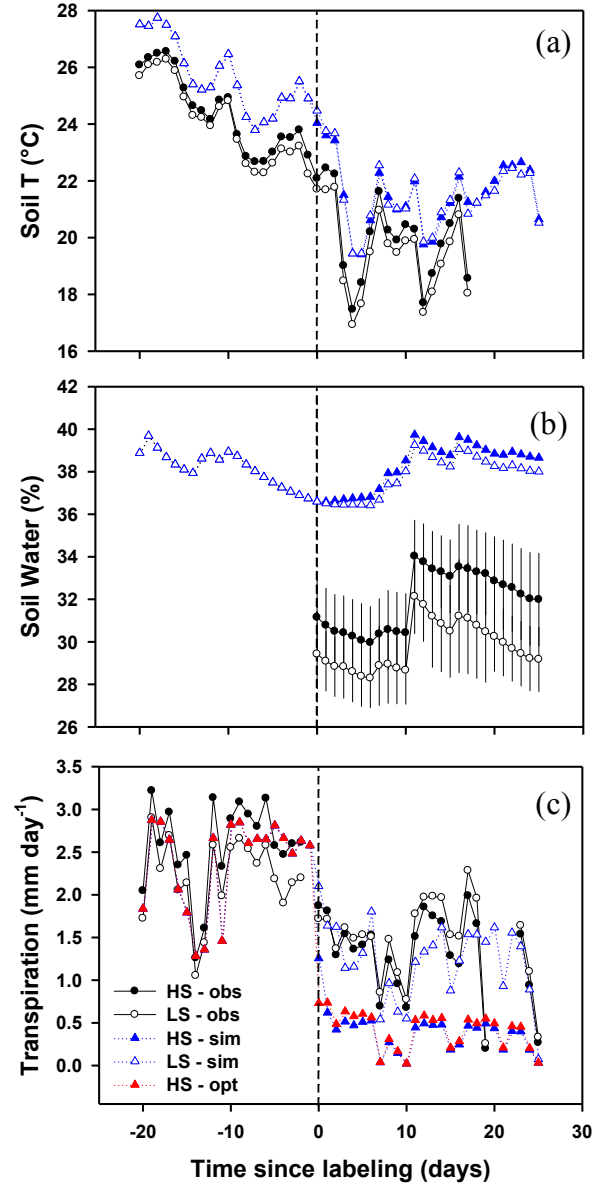

Figure 4. (a) Observed (obs) and CLM simulated (sim) daily soil temperature at $0-5 \mathrm{~cm}$ depth $\left(\mathrm{SD}=0.6-1.4^{\circ} \mathrm{C}\right)$, (b) volumetric soil water content at $15-95 \mathrm{~cm}$ depth $( \pm \mathrm{SD})$, and (c) the transpiration before and after initiation of light shade (LS) or heavy shade (HS) treatments $\left(\mathrm{SD}=0.1-1.7 \mathrm{~mm} \mathrm{day}^{-1}\right)$. HS-opt represents the CLM simulation with optimized leaf conductance parameters. The vertical dashed lines indicate the starting day of the shade treatments.

\section{Discussion}

\subsection{Assessment of model performance in pretreatment period}

Default model physiological parameters most appropriate to our site are based on averages taken across numerous data sets collected in evergreen needleleaf forests. There is considerable variation within that broad type classification for all of the measured parameters (White et al., 2000), and any time a site-level evaluation is used to assess model behavior (as here) it is helpful to constrain within this range according to the local species or species mixture. We used measurements taken directly from the site where available and constrained the optimization of other parameters based on the observed ranges for loblolly pine, when available. The fine-root-toleaf allocation ratio increased from 1.0 to 1.24 , which is well
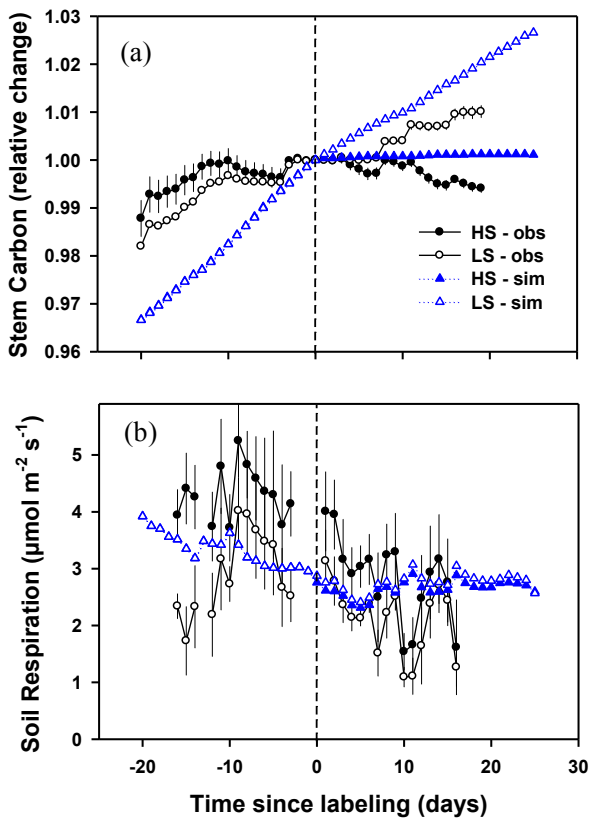

Figure 5. (a) Observed (obs) and CLM simulated (sim) daily stem carbon relative to day $0( \pm \mathrm{SD})$; (b) soil respiration prior to and after exposure to light shade (LS) and heavy shade (HS) treatments $( \pm \mathrm{SD})$. Both observed and simulated stem carbon were normalized to 1 at day 0 . The simulated soil respiration is the combination of autotrophic respiration from roots and heterotrophic respiration from the decay of litter and soil organic matter. The vertical dashed lines indicate the starting day of the treatments.

within the range of reported values (White et al., 2000). The fraction of leaf nitrogen in RuBisCO was $70 \%$ higher than the model default value and, while on the high end, is consistent with measurements of other loblolly pine trees (Tissue et al., 1995). The temperature sensitivity of maintenance respiration $\left(Q_{10 \mathrm{mr}}\right)$ nearly doubled from the default value of 1.5 to 2.83. This is higher than most values in the literature but is consistent with the value of 2.71 reported by Hamilton et al. (2001) for loblolly pine, although this value only pertains to leaf respiration. The optimized value for stem to leaf allocation ratio also is higher than in the default model, but it falls well within the observed range for loblolly pine (White et al., 2000).

The optimized model delivered very reasonable simulations of pretreatment tree biomass, transpiration, and leaf $\delta^{13} \mathrm{C}$ (Figs. 3a, 4c, and 6a). Including multiple independent observational metrics in the optimization cost function is a more challenging test of correct model structure compared to optimization targeting a single model output variable (Sacks et al., 2006; Richardson et al., 2010; Ricciuto et al., 2011). The fact that our optimized model delivers good results for all three components simultaneously (biomass, transpiration, and leaf $\delta^{13} \mathrm{C}$ ) supports the notion that stand-scale model structure is reasonable. 

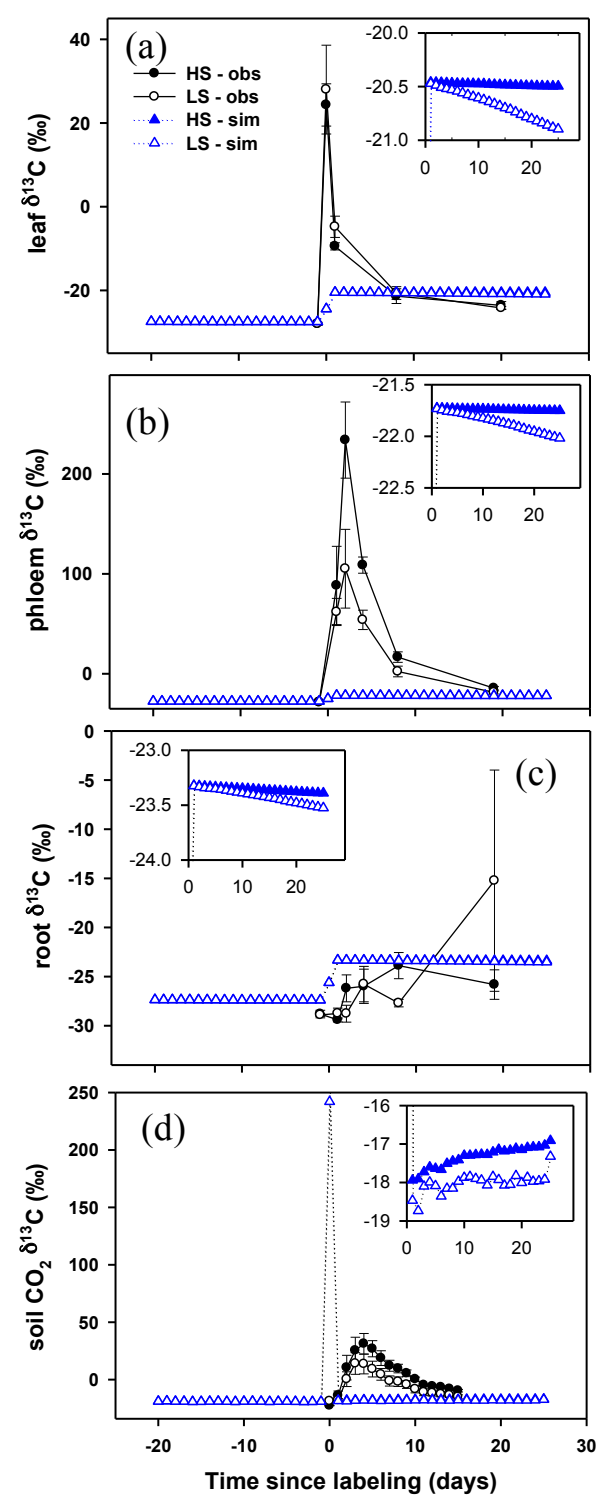

Figure 6. Observed (black) and CLM simulated (blue) change in $\delta^{13} \mathrm{C}$ (parts per thousand, \%o) of (a) leaf, (b) phloem, (c) bulk root, and (d) soil surface efflux $\delta^{13} \mathrm{C}$ for the light shade (LS, open circle) and heavy shade (HS, filled circle) pretreatment and treatment periods ( \pm standard error). The modeled $\delta^{13} \mathrm{C}$ values were calculated from the CLM simulated ${ }^{13} \mathrm{C}$ and ${ }^{12} \mathrm{C}$ variables and the reference standard (0.0112372) using the equation described in https://en.wikipedia.org/wiki/ $\Delta 13 \mathrm{C}$. The ${ }^{13} \mathrm{CO}_{2}$ labeling pulse was initiated on 1 September in year 2010 (day 0). To better visualize the model results, inset figures illustrate the CLM simulated $\delta^{13} \mathrm{C}$ values for the light shade (open triangle) and heavy shade (filled triangle) treatments from day 1 to day 25 .

Independent evaluation of model results at the leaf scale demonstrated that the optimized parameters either reduced biases (LS and open-field light levels) or gave mixed results (HS light levels) at this scale. This provides additional confirmation that the optimization approach was reasonable and was not generating unrealistic parameter values to compensate for gross structural deficiencies in the model. This is further confirmed by the fact that optimized parameters ( $\mathrm{Ta}$ ble 1) controlling stomatal conductance changed only modestly from default values.

Independent evaluation of model against pretreatment $\delta^{13} \mathrm{C}$ in phloem and in soil surface $\mathrm{CO}_{2}$ shows good agreement, consistent with the targeted pretreatment value for $\delta^{13} \mathrm{C}$ in leaves. Simulated bulk root $\delta^{13} \mathrm{C}$ is biased slightly high (Fig. 6c), indicating possible errors in root turnover time or the model's failure to account for post-photosynthetic fractionation (Badeck et al., 2005).

Though several changes in the canopy photosynthesis scheme were made in the version 4.5 of CLM (Bonan et al., 2011; Oleson et al., 2013), in this work the canopy photosynthesis process of CLM4 did a reasonably good job against our evaluation metrics, including the leaf-level lightresponse data. The ability of our optimized model to reproduce pretreatment biomass, transpiration, ${ }^{13} \mathrm{C}$ discrimination, and leaf-scale photosynthetic response to light gives confidence in the model's ability to simulate the shading effect and the model's ability to scale leaf-level processes to growth at the whole-tree scale.

\subsection{Assessment of model performance in treatment period}

We did not attempt to optimize model predictions for soil temperature or soil moisture content. The model overestimation of soil temperature while faithfully reproducing the multi-day excursions in temperature is consistent through the pretreatment and treatment periods. Soil surface temperatures were not measured, so it is not clear whether the overestimation bias is related to a surface energy balance bias, to a bias in the overlying air temperature, or to parameterization error in thermal diffusivity and its relationship to soil texture and surface layer properties.

The overestimation bias in modeled soil moisture during the treatment period (there were no pretreatment observations) suggests a parameterization error for soil texture or variation in texture with depth. Small differences in the clay fraction, for example, could cause the observed offset in mean soil water content, and clearly there is variability in soil moisture states across the site, both within and between the shade treatments (Fig. 4b). We used a single estimate of sand, silt, and clay fractions from the site, and we were satisfied that the model was able to capture pretreatment transpiration with that soil parameterization and that the multiday excursions of soil moisture were of similar magnitude in the model compared to observations during the treatment period. We also note that modeled stomatal conductance was not impacted by lack of soil water in these simulations. Periodic rainfall kept soils relatively wet throughout the pretreatment and treatment periods, minimizing effects of bias in soil moisture on simulated photosynthesis or transpiration. 
The very large difference between modeled and measured transpiration for the HS treatment is the most confounding result from our study. The model carbon and water dynamics are well behaved for the pretreatment period, and the model also captures the influence of light shading on transpiration accurately. Stem growth results indicate that reduced growth of LS trees and the cessation of growth for HS trees, is captured properly by the model. Through the Ball-Berry approximation linking stomatal conductance to photosynthetic rate, the model is forced into a state of reduced transpiration for the HS treatment, even with additional optimization that placed Ball-Berry parameters at their outer observational limits. It is possible that the sap-flow measurements in the HS treatment are biased, and that the actual tree-scale transpiration is not as high as suggested by these measurements, but if true we would expect that bias to occur for both pretreatment and treatment periods and not only, as observed, to appear in the treatment period. Connected to that hypothesis, it is possible that while actual leaf stomatal conductance shut down during the HS treatment, water continued to accumulate in the stem, moving past the sap-flow sensors and filling a capacitance in the xylem tissue. However, the sustained sap flow over the long duration of the treatment period and the negative observed trend in stem diameter for HS trees argue against that interpretation.

Alternatively, if we assume that the sap-flow measurements reflect actual high levels of transpiration in the HS trees, then we are forced to conclude that the Ball-Berry relationship as implemented in CLM (De Kauwe et al., 2013; Oleson et al., 2010, 2013) breaks down under these rather extreme experimental conditions. Under that hypothesis, it would seem that there is some "memory" of the expected range of light levels in the tree and, even when photosynthesis is nearly extinguished due to experimentally forced reduction in PAR, stomatal conductance remains at a relatively high level. Another possibility is that these trees exhibit a strong nonlinearity in the relationship between stomatal conductance and net photosynthesis, which has been observed at low light levels and strongly impacts estimated transpiration (Barnard and Bauerle, 2013). This type of nocturnal transpiration may indeed have been greater for the HS trees if the vapor pressure deficit were larger (Domec et al., 2012). Errors in modeled leaf temperature and leaf boundary layer vapor pressure deficit may also contribute to the discrepancy with observations. Conductance may have been maintained to some extent by vapor pressure differences between the foliage and the shade cloth - indeed, dew was observed on unshaded trees in early morning, yet not on the shaded trees. This hypothesis could be tested in future studies with additional leaf-level measurements under HS treatments, sampling both the diurnal cycle and the multi-day behavior of leaf physiology in trees subjected to high levels of shading. While the HS conditions are unlikely to be realized for extended periods under natural conditions, understanding this failure of the commonly used Ball-Berry parameter- ization may be helpful in understanding and predicting the broader case of adaptation of stomatal behavior to environmental change, which is known to influence water and carbon cycle predictions under future climates (Damour et al., 2010).

Stem diameter can shrink or swell based on changes in stem xylem water content, bark water content, and cambial growth and is dependent on xylem water potential, vapor pressure deficit, $\mathrm{C}$ availability, non-structural carbohydrate concentrations, and $\mathrm{C}$ allocation (Vandegehuchte et al., 2014). C allocation to stem growth is revealed by a step-wise increase in stem diameter that occurs in response to favorable conditions and maintained under less favorable conditions. The LS treatment clearly displayed the step-wise increases in stem diameter, while the HS treatment displayed a reduction in stem diameter. The shrinking stem diameter of HS trees indicates a decline in xylem and phloem water content likely linked to phloem sugar concentration. The HS treatment certainly reduced foliar $\mathrm{C}$ uptake and $\mathrm{C}$ available for phloem loading and allocation to cambial growth (Warren et al., 2012).

The modeled difference between LS and HS in biomass accumulation in stems is in good agreement with observations based on stem diameter, with increases of 1.9 and $1.6 \%$ by treatment day 19 for model and observations, respectively (Fig. 5a). Given the previously discussed pretreatment results for biomass accumulation and leaf-scale photosynthesis, we are confident in the optimized model's ability to capture carbon dynamics at the plant scale on timescales of years to tens of days. It is reassuring to see that the model prediction of soil respiration falls in the observed range, although this could be the result of good luck as much as good performance. While soil respiration on an annual basis is closely related to litter inputs and belowground plant respiration, it is possible for compensating errors between decomposition rates and litter inputs, or between litter inputs and root respiration, to result in good model-observation agreement for the approximately monthly timescale examined here. We note a potential bias in the model relationship between soil respiration and soil moisture: while the observed soil respiration is depressed after large precipitation events, the model estimates an increase. Neither CLM4's carbon allocation to roots nor its predicted root respiration is dependent on soil water conditions. CLM4's heterotrophic contribution to soil respiration may also have too little sensitivity and the timing of soil respiration response to soil water variation may also be too simplistic. A more mechanistic treatment of water-airmicrobe interactions at the scale of soil pore space might help to eliminate these differences. Resolved vertical transport of respired $\mathrm{CO}_{2}$ in the soil column might also help to correct this bias.

Beyond noting the obvious discrepancy in observed vs. modeled $\delta^{13} \mathrm{C}$ dynamics associated with the lack of shortterm photosynthate storage pools in CLM, we are interested in using this study to develop hypotheses explaining the ob- 
served patterns in $\delta^{13} \mathrm{C}$, identifying the simplest mechanisms that explain observed patterns, and understanding the consequences of ignoring those mechanisms in a model like CLM. To the extent that simple mechanisms can be identified, and significant consequences of ignoring those mechanisms articulated, we leave it to future efforts to deploy and evaluate those mechanisms in new model versions and with new observational and experimental constraints.

Given that LS and HS leaves seem to have photosynthesized the pre-shading labeled pulse of $\mathrm{CO}_{2}$ at similar rates (Fig. 6a) as intended by the experimental design, we can make some inferences about the dynamics of photosynthate storage and transport based on the timing of the pulse as it exits the foliage and passes through the phloem of the trunk and based on differences in timing and concentration of the labeled pulse in LS and HS trees. First, the fact that observed peak label concentration is higher in phloem than in foliage, even though that peak comes 2 days later in phloem than in foliage, indicates that the phloem pool in the vicinity of the labeling source (the leaf) is smaller than the leaf pool itself. That is, even though the label is passing into the leaf prior to entering the phloem, the label pulse is relatively small compared to the leaf carbon pool as a whole, while it is relatively large compared to the part of the phloem pool nearest the leaf at the time of labeling. Second, the observation that $\delta^{13} \mathrm{C}$ in foliage declines rapidly over the first 10 days, and declines at about the same rate for LS and HS leaves, indicates that the movement of newly fixed photosynthate from leaves and into phloem does not depend strongly on production of new photosynthate in subsequent days. Third, the similar timing between LS and HS trees for peak label concentration in phloem, and later in soil surface $\mathrm{CO}_{2}$, indicates that the velocity of material movement through the phloem does not depend strongly on current photosynthesis rate. Since the HS treatment clearly reduced growth and transport belowground (Fig. 5), the logical conclusion is that the cross-sectional area of active phloem tissue responsible for transport of photosynthate away from leaves and out to roots is lower in the HS than in the LS treatment. One possible interpretation is that the rate of flow within a given phloem pathway is relatively constant, and more phloem pathways towards the roots are active when production of photosynthate is high. A logical consequence of that arrangement would be that at any given point along the transport pathway towards the roots, or at any point in time at a given location along the pathway, the concentration of a common-sized label would be lower for a tree with high rate of ongoing photosynthesis than for a tree with low rate of ongoing photosynthesis, due to dilution of the fixed-size label into a larger number (larger cross-sectional area) of transport pathways, all with a common transport velocity (conceptual model shown in Fig. 7). This is in fact the observed relationship of LS to HS concentration at all points in time for both the phloem measurements (fixed point on the trunk) and for the soil surface $\mathrm{CO}_{2}$, lending support to the hypothesized mechanism.

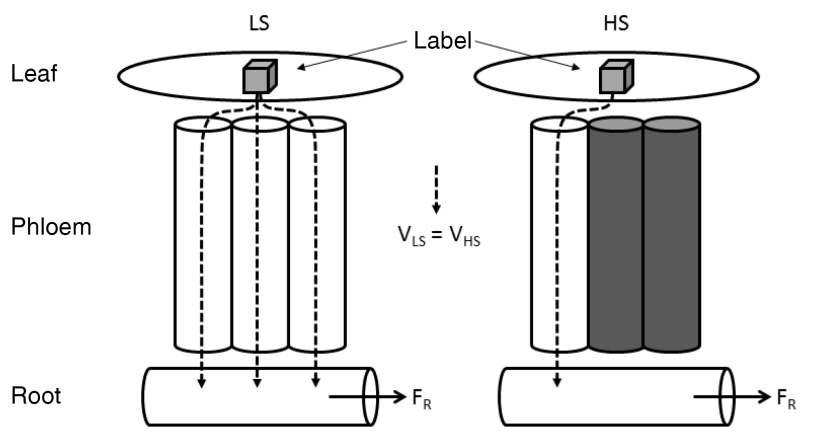

Figure 7. Conceptual model of label transport, assuming a constant velocity $(V)$ of phloem stream with a cross-sectional area for the phloem pathway that varies as a function of ongoing photosynthetic rate. The cross-sectional area is conceptualized here as a varying number of similar phloem elements, with white elements in an active state and dark elements inactive. The experimental case with a higher photosynthetic rate for the LS treatment and lower photosynthetic rate for the HS treatment is illustrated. Flux from roots $\left(F_{\mathrm{R}}\right)$ includes root respiration, root exudation, and turnover of root tissue. The entire label is assumed to exit the leaf and enter the active phloem stream at a rate that is independent of the ongoing rate of photosynthesis, as observed in the experiment.

Plant storage pools in the form of non-structural carbohydrates are known to play an important role in regulating allocation to structural pools, and they may make up a significant portion of total biomass (e.g., Hoch et al., 2003). Simple models that account for non-structural carbohydrates better compare with observed ${ }^{14} \mathrm{C}$ and stem growth, indicating the importance of the pools over seasonal to decadal timescales (Richardson et al., 2013). The question remains: what are the consequences for a CLM like model of ignoring the shorter timescale (monthly) storage dynamics? (see Fig. 7). If we show that the modeled and observed label concentrations tend to converge over monthly timescales, we can argue that ignoring these short-term pools is not a first-order impediment to good estimates of allocation and growth. Other more subtle aspects of the problem could, however, have important implications for plot-scale and even global-scale vegetationsoil ecosystem dynamics and feedbacks. For example, the labeled soil surface $\mathrm{CO}_{2}$ efflux is a result from a combination of root respiration and heterotrophic respiration. The heterotrophic component can be supplied by fresh litter inputs or by root exudation of non-structural carbohydrate, which can be a significant fraction of net primary production in some systems (Högberg et al., 2010). The difference between root mortality and root exudation in terms of substrate quality, nutrient content, and interactions with soil microbial communities could be very significant, especially as integrated over long periods and under conditions of changing climate, changing atmospheric $\mathrm{CO}_{2}$ concentration, and anthropogenic modifications to nutrient cycles. 
Representing the existence and dynamics of short-term photosynthate storage pools in a model like CLM could also help to resolve the mechanisms relating nutrient mineralization and availability in soils with plant-microbe competition for available nutrients and the influence of nutrient uptake on leaf-scale photosynthesis. In addition to the shading treatments described here, other manipulations that would be useful to explore include elevated $\mathrm{CO}_{2}$ during and/or after the labeling pulse, imposed nutrient limitations, and fertilization. Replicating these studies in other vegetation types would help to assess the generality of storage pool structure and function and would support operational inclusion of these mechanisms in a global-scale model.

\subsection{Implications for experimental design}

Limitations identified in this first PiTS model-experiment interaction have already led to improvements in follow-on experiments. For new experiments in a nearby dogwood stand, additional observations include multiple treatments in different seasons, a collection of absolute destructive tree biomass at the end of the study (rather than highly uncertain estimates based on allometric relationships), seasonal leaf-level photosynthetic measurements, assessment of mycorrhizal C flux, and improved meteorological measurements. Although model parameters can be improved through optimization as in this study, model parameters are being measured where possible. These additional observational data are necessary for more detailed model evaluation and improvement of model routines of $\mathrm{C}$ and allocation patterns at various timescales. Additional effort is being devoted to characterizing the system prior to manipulation, including measurements of biomass, soil physical, and soil biogeochemical states.

\section{Conclusions}

The point version of CLM4 was implemented, calibrated, and evaluated against carbon and hydrology observations from a shading and labeling experiment in a stand of young loblolly pines. We found that a combination of parameters measured on-site and calibration targeting biomass, transpiration, and ${ }^{13} \mathrm{C}$ discrimination gave good agreement with pretreatment measurements, including independent evaluation metrics at the leaf scale. We showed that the calibrated model captured the tree-scale and monthly temporal dynamics of a light shade treatment as it influenced carbon and water fluxes. The calibrated model also captured the monthly timescale carbon dynamics of a heavy shade treatment, but it persistently estimated low levels of transpiration for the heavy shade treatment, while observed transpiration in that treatment remained nearly as high as for the light shade. We have suggested several possible explanations for the discrep- ancy, but this remains a puzzling problem requiring further investigation.

Although the model lacks short-term photosynthate storage and transport mechanisms that are clearly present in the real plants, first-order monthly timescale dynamics for carbon allocation and growth do not seem to suffer greatly. We used observations from the experiment to develop a conceptual model (hypothesis) of short-term photosynthate storage and transport and suggested further studies that could be carried out to evaluate the generality of the hypothesized mechanisms. We suggest several research problems, which, if the proposed mechanism turns out to be generally valid, would benefit from model-experimental study in which the new mechanisms are incorporated into the model structure.

Acknowledgements. This work is supported by the US Department of Energy (DOE), Office of Science, Biological and Environmental Research. Oak Ridge National Laboratory is managed by UT-BATTELLE for DOE under contract DE-AC05-00OR22725.

Edited by: T. Keenan

\section{References}

Amthor, J. S., Chen, J. M., Clein, J. S., Frolking, S. E., Goulden, M. L., Grant, R. F., Kimball, J. S., King, A. W., McGuire, A. D., Nikolov, N. T., Potter, C. S., Wang, S., and Wofsy, S. C.: Boreal forest $\mathrm{CO}_{2}$ exchange and evapotranspiration predicted by nine ecosystem process models: Intermodel comparisons and relationships to field measurements, J. Geophys. Res.-Atmos., 106, 33623-33648, 2001.

Arora, V. K., Boer, G. J., Friedlingstein, P., Eby, M., Jones, C. D., Christian, J. R., Bonan, G., Bopp, L., Brovkin, V., and Cadule, P.: Carbon-concentration and carbon-climate feedbacks in CMIP5 Earth system models, J. Climate, 26, 5289-5314, 2013.

Atkin, O.: New phytologist and the "fate" of carbon in terrestrial ecosystem, New Phytol., 205, 1-3, 2015.

Badeck, F. W., Tcherkez, G., Nogues, S., Piel, C., and Ghashghaie, J.: Post-photo synthetic fractionation of stable carbon isotopes between plant organs - a widespread phenomenon, Rapid Commun. Mass Sp., 19, 1381-1391, 2005.

Bahn, M., Buchmann, N., and Knohl, A.: Preface "Stable Isotopes and Biogeochemical Cycles in Terrestrial Ecosystems", Biogeosciences, 9, 3979-3981, doi:10.5194/bg-9-3979-2012, 2012

Baldocchi, D., Falge, E., Gu, L., Olson, R., Hollinger, D., Running, S., Anthoni, P., Bernhofer, C., Davis, K., and Evans R.: FLUXNET: A new tool to study the temporal and spatial variability of ecosystem-scale carbon dioxide, water vapor, and energy flux densities, B. Am. Meteorol. Soc., 82, 2415-2434, 2001.

Baldwin, V. C. and Feduccia, D. P.: Loblolly pine growth and yield prediction for managed west Gulf plantations, USDA For. Ser. Res. Pap., SO-236, New Orleans, LA: U.S. Department of Agriculture, Forest Service, Southern Forest Experiment Station, USA, 27 pp., 1987. 
Barnard, D. M. and Bauerle, W. L.: The implications of minimum stomatal conductance on modeling water flux in forest canopies, J. Geophys. Res.-Biogeo., 118, 1322-1333, 2013.

Bauerle, W. L., Oren, R., Way, D. A., Qian, S. S., Stoy, P. C., Thornton, P. E., Bowden, J. D., Hoffman, F. M., and Reynolds, R. F.:, Photoperiodic regulation of the seasonal pattern of photosynthetic capacity and the implications for carbon cycling, P. Natl. Acad. Sci. USA, 109, 8612-8617, 2012.

Beer, C., Reichstein, M., Tomerlleri, E., Ciais, P., Jung, M., Carvalhai, N., Rodenbeck, C., Arain, M. A., Baldocchi, D., Bonan, G. B., Bondeau, A., Cescatti, A., Lasslop, G., Lindroth, A., Lomas, M., Luyssaert, S., Margolis, H., Oleson, K. W., Roupsard, O., Veenendaal, E., Viovy, N., Williams, C., Woodward, F. I., and Papale, D.: Terrestrial gross carbon dioxide uptake: global distribution and covariation with climate, Science, 329, 834-838, 2010.

Best, M. J., Pryor, M., Clark, D. B., Rooney, G. G., Essery, R .L. H., Ménard, C. B., Edwards, J. M., Hendry, M. A., Porson, A., Gedney, N., Mercado, L. M., Sitch, S., Blyth, E., Boucher, O., Cox, P. M., Grimmond, C. S. B., and Harding, R. J.: The Joint UK Land Environment Simulator (JULES), model description Part 1: Energy and water fluxes, Geosci. Model Dev., 4, 677-699, doi:10.5194/gmd-4-677-2011, 2011.

Bonan, G. B., Lawrence, P. J., Oleson, K. W., Levis, S., Jung, M., Reichstein, M., Lawrence, D. M., and Swenson, S. C.: Improving canopy processes in the Community Land Model version 4 (CLM4) using global flux fields empirically inferred from FLUXNET data, J. Geophys. Res., 116, G02014, doi:10.1029/2010JG001593, 2011.

Bonan, G. B., Oleson, K. W., Fisher, R. A., Lasslop, G., and Reichstein, M.: Reconciling leaf physiological traits and canopy flux data: Use of the TRY and FLUXNET databases in the Community Land Model version 4, J. Geophys. Res., 117, G02026, doi:10.1029/2011JG001913, 2012.

Bonan, G. B., Hartman, M. D., Parton, W. J., and Wieder, W. R.: Evaluating litter decomposition in earth system models with long-term litterbag experiments: an example using the Community Land Model version 4 (CLM4), Glob. Change Biol., 19, 957-974, 2013.

Cannell, M. G. R. and Dewar R. C.: Carbon allocation in trees - a review of concepts for modeling, Adv. Ecol. Res., 25, 59-104, 1994.

Dai, Y. J., Zeng, X. B., Dickinson, R. E., Baker, I., Bonan, G. B., Bosilovich, M. G., Denning, A. S., Dimeyer, P. A., Houser, P. A., Niu, G. Y., Oleson, K. W., Scholosser, C. A., and Yang, Z., L.: The common land model, B. Am. Meteorol. Soc., 84, 10131023, doi:10.1175/BAMS-84-8-1013, 2003.

Damour, G., Simonneau, T., Cochard, H., and Urban, L.: An overview of models of stomatal conductance at the leaf level, Plant Cell Environ., 33, 1419-1438, 2010.

De Kauwe, M. G., Medlyn, B. E., Zaehle, S., Walker, A. P., Dietze, M. C., Hickler, T., Jain, A. K., Luo, Y. Q., Parton, W. J., Prentice, I. C., Smith, B., Thornton, P. E., Wang, S. S., Wang, Y. P., Warlind, D., Weng, E. S., Crous, K. Y., Ellsworth, D. S., Hanson, P. J., Seok Kim, H., Warren, J. M., Oren, R., and Norby R. J.,: Forest water use and water use efficiency at elevated $\mathrm{CO}_{2}$ : a model-data intercomparison at two contrasting temperate forest FACE sites, Glob. Change Biol., 19, 1759-1779, 2013.
De Kauwe, M. G., Medlyn, B. E., Zaehle, S., Walker, A. P., Dietze, M. C., Wang, Y. P., Luo, Y. Q., Jain, A. K., El-Masri, B., Hickler, T., Warlind, D., Weng, E. S., Parton, W. J., Thornton, P. E., Wang, S. S., Prentice, I. C., Asao, S., Smith, B., McCarthy, H. R., Iversen, C. M., Hanson, P. J., Warren, J. M., Oren, R., and Norby, R. J.: Where does the carbon go? A model-data intercomparison of vegetation carbon allocation and turnover processes at two temperate forest free-air $\mathrm{CO}_{2}$ enrichment sites, New Phytol., 203, 883-899, 2014.

Domec J. C., Ogée, J., Noormets, A., Jouangy, J., Gavazzi, M., Treasure, E., Sun, G., McNulty, S., and King, J. S.: Interactive effects of nocturnal transpiration and climate change on the root hydraulic redistribution and carbon and water budgets of Southern US pine plantations, Tree Physiol., 32, 707-723, 2012.

Ehleringer, J. R., Buchmann, N., and Flanagan, L. B.: Carbon isotope ratios in belowground carbon cycle processes, Ecol. Appl., 10, 412-422, 2000.

Epron, D., Bahn, M., Derrien, D., Lattanzi, F. A., Pumpanen, J., Gessler, A., Hogberg, P., Maillard, P., Dannoura, M., Gerant, D., and Buchmann, N.: Pulse-labelling trees to study carbon allocation dynamics: a review of methods, current knowledge and future prospects, Tree Physiol., 32, 776-798, 2012.

Farquhar, G. D., Ehleringer, J. R., and Hubick, K. T.: Carbon Isotope Discrimination and Photosynthesis, Annu. Rev. Plant Phys., 40, 503-537, 1989.

Fox, A., Williams, M., Richardson, A. D., Cameron, D., Gove, J. H., Quaife, T., Ricciuto, D., Reichstein, M., Tomelleri, E., Trudinger, C. M., and Van Wijk, M. T.: The REFLEX project: Comparing different algorithms and implementations for the inversion of a terrestrial ecosystem model against eddy covariance data, Agr. Forest Meteorol., 149, 1597-1615, 2009.

Friedlingstein, P., Cox, P., Betts, R., Bopp, L., Von Bloh, W., Brovkin, V., Cadule, P., Doney, S., Eby, M., Fung, I., Bala, G., John, J., Jones, C., Joos, F., Kato, T., Kawamiya, M., Knorr, W., Lindsay, K., Matthews, H. D., Raddatz, T., Rayner, P., Reick, C., Roeckner, E., Schnitzler, K. G., Schnur, R., Strassmann, K., Weaver, A. J., Yoshikawa, C., and Zeng, N.: Climate-carbon cycle feedback analysis: Results from the (CMIP)-M-4 model intercomparison, J. Climate, 19, 3337-3353, 2006.

Gent, P. R., Danabasoglu, G., Donner L. J., Holland, M. M., Hunke, E. C., Jayne, S. R., Lawrence, K. M., Neale, R. B., Rasch, P. J., Vertenstein, M., Worley P. H., Yang, Z. L, and Zhang, M. H.: The Community Climate System Model Version 4, J. Climate, 24, 4973-4991, 2011.

Griffin, K. L., Winner, W. E., and Strain, B. R.: Growth and dry matter partitioning in loblolly and ponderosa pine seedlings in response to carbon and nitrogen availability, New Phytol., 129, 547-556, 1995.

Hamilton, J. G., Thomas, R. B., and Delucia, E. H.: Direct and indirect effects of elevated $\mathrm{CO}_{2}$ on leaf respiration in a forest ecosystem, Plant Cell Environ., 24, 975-982, 2001.

Hanson, P. J., Amthor, J. S., Wullschleger, S. D., Wilson, K. B., Grant, R. F., Hartley, A., Hui, D., Hunt, E. R., Johnson, D. W., Kimball, J. S., King, A. W., Luo, Y., McNulty, S. G., Sun, G., Thornton, P. E., Wang, S., Williams, M. Baldocchi, D. D., and Cushman, R. M.: Oak forest carbon and water simulations: Model intercomparisons and evaluations against independent data, Ecol Monogr., 74, 443-489. 2004. 
Hoch, G., Richter, A., and Korner, C.: Non-structural carbon compounds in temperate forest trees, Plant Cell Environ., 26, 10671081, 2003.

Högberg, M. N., Briones, M. J. I., Keel, S. G., Metcalfe, D. B., Campbell, C., Midwood, A. J., Thornton, B., Hurry, V., Linder, S., Näsholm, T., and Högberg, P.: Quantification of effects of season and nitrogen supply on tree below-ground carbon transfer to ectomycorrhizal fungi and other soil organisms in a boreal pine forest, New Phytol., 187, 485-493, 2010.

Huntzinger, D. N., Post, W. M., Wei, Y., Michalak, A. M., West, T. O., Jacobson, A. R., Baker, I. T., Chen, J. M, Davis, K. J., Hayes, D. J., Hoffman, F. M., Jain, A. K., Liu, S., McGuire, A. D., Neilson, R. P., Potter, C., Poulter, B., Price, D., Raczka, B. M., Tian, H. Q., Thornton, P. E., Tomelleri, E., Viovy, N., Xiao, J., Yuan, W., Zeng, N., Zhao, M., and Cook, R.: North American Carbon Program (NACP) regional interim synthesis: Terrestrial biospheric model intercomparison, Ecol. Model., 232, 144-157, 2012.

Idso, S. B.: A set of equations for full spectrum and 8- to 14- $\mu \mathrm{m}$ and 10.5- to 12.5 - $\mu$ m thermal-radiation from cloudless skies, Water Resour. Res., 17., 295-304, 1981.

Keenan, T. F., Carbone, M. S., Reichstein, M., and Richardson, A. D.: The model-data fusion pitfall: assuming certainty in an uncertain world, Oecologia, 167, 587-597, 2011.

Koven, C. D., Riley, W. J., Subin, Z. M., Tang, J. Y., Torn, M. S., Collins, W. D., Bonan, G. B., Lawrence, D. M., and Swenson, S. C.: The effect of vertically resolved soil biogeochemistry and alternate soil $\mathrm{C}$ and $\mathrm{N}$ models on C dynamics of CLM4, Biogeosciences, 10, 7109-7131, doi:10.5194/bg-10-7109-2013, 2013.

Krinner, G., Viovy, N., de Noblet-Ducoudre, N., Ogee, J., Polcher, J., Friedlingstein, P., Ciais, P., Sitch, S., and Prentice, I. C.: A dynamic global vegetation model for studies of the coupled atmosphere-biosphere system, Global Biogeochem. Cy., 19, GB1015, doi:10.1029/2003GB002199, 2005.

Lawrence, D. M., Oleson, K. W., Fanner, M. G., Thornton, P. E., Swenson, S. C., Lawrence, P. J., Zeng, X. B., Yang, Z. L., Levis, S., Sakaguchi, K., Bonan, G. B., and Slater, A. G.: Parameterization improvements and functional and structural advances in version 4 of the Community Land Model, J. Adv. Model. Earth Syst., 3, M03001, doi:10.1029/2011MS000045, 2011.

Litton, C. M., Raich, J. W., and Ryan, M. G.: Carbon allocation in forest ecosystems, Glob. Change Biol., 13, 2089-2109, 2007.

Luo, Y. Q., Randerson, J. T., Abramowitz, G., Bacour, C., Blyth, E., Carvalhais, N., Ciais, P., Dalmonech, D., Fisher, J. B., Fisher, R., Friedlingstein, P., Hibbard, K., Hoffman, F., Huntzinger, D., Jones, C. D., Koven, C., Lawrence, D., Li, D. J., Mahecha, M., Niu, S. L., Norby, R., Piao, S. L., Qi, X., Peylin, P., Prentice, I. C., Riley, W., Reichstein, M., Schwalm, C., Wang, Y. P., Xia, J. Y., Zaehle, S., and Zhou, X. H.: A framework for benchmarking land models, Biogeosciences, 9, 3857-3874, doi:10.5194/bg-93857-2012, 2012.

Mao, J., Shi, X., Thornton, P. E., Piao, S. L., and Wang, X. H.: Causes of spring vegetation growth trends in the northern midhigh latitudes from 1982 to 2004, Environ. Res. Lett., 7, 014010 , doi:10.1088/1748-9326/7/1/014010, 2012a.

Mao, J., Thornton, P. E., Shi, X., Zhao, M. S., and Post, W. M.: Remote sensing evaluation of CLM4 GPP for the period 200009, J. Climate, 25, 5327-5342, 2012b.
Mao, J., Shi, X., Thornton, P. E., Hoffman, F. M., Zhu, Z. C., and Myneni, R. B.: Global latitudinal-asymmetric vegetation growth trends and their driving mechanisms: 1982-2009, Remote Sens., 5, 1484-1497, 2013.

Naidu, S. L., DeLucia, E. H., and Thomas, R. B.: Contrasting patterns of biomass allocation in dominant and suppressed loblolly pine, Can. J. Forest Res., 28, 1116-1124, 1998.

Oleson, K. W., Lawrence, D. M., Bonan, G. B., Drewniak, B., Huang, M., Koven, C. D., Levis, S., Li, F., Riley, W. J., Subin, Z. M., Swenson, S., Thornton, P. E., Bozbiyik, A., Fisher R., Heald, C. L., Kluzek, E., Lamarque, J.-F., Lawrence, P. J., Leung, L. R., Lipscomb, W., Muszala, S. P., Ricciuto, D. M., Sacks, W. J., Sun, Y., Tang, J., and Yang, Z.-L.: Technical description of version 4.5 of the Community Land Model (CLM), NCAR Technical Note NCAR/TN-503+STR, The National Center for Atmospheric Research (NCAR), Boulder, CO, USA, 420 pp., 2013.

Oleson, K. W., Niu, G.-Y., Yang, Z.-L., Lawrence, D. M., Thornton, P. E., Lawrence, P. J., Stoeckli, R., Dickinson, R. E., Bonan, G. B., Levis, S., Dai, A., and Qian, T.: Improvements to the Community Land Model and their impact on the hydrological cycle, J. Geophys. Res.-Biogeo., 113, G01021, doi:10.1029/2007JG000563, 2008.

Oleson, K. W., Lawrence, D. M., Gordon, B., Flanner, M. G., Kluzek, E., Lawrence, P. J., Levis, S., Swenson, S. C., Thornton, P. E., Dai, A., Decker, M., Dickinson, R., Feddema, J., Heald, C. L., Hoffman, F., Lamarque, J.-F., Mahowald, N., Niu, G.-Y., Qian, T., Randerson, J., Running, S., Sakaguchi, K., Slater, A., Stoeckli, R., Wang, A, Yang, Z.-L., Zeng, X. D., and Zeng, X. B.: Technical description of version 4.0 of the Community Land Model (CLM), NCAR Technical Note NCAR/TN 478+STR; The National Center for Atmospheric Research (NCAR), Boulder, CO, USA, 257 pp., 2010.

Ostle, N. J., Smith, P., Fisher, R., Woodward, F. I., Fisher, J. B., Smith, J. U., Galbraith, D., Levy, P., Meir, P., McNamar, N. P., and Bardgett, R. D.: Integrating plant-soil interactions into global carbon cycle models, J. Ecol., 97, 851-863, 2009.

Pitman, A. J.: The evolution of, and revolution in, land surface schemes designed for climate models, Int. J. Climatol., 23, 479510, 2003.

Raczka, B. M., Davis, K. J., Huntzinger, D., Neilson, R. P., Poulter, B., Richardson, A. D., Xiao, J. F., Baker, I., Ciais, P., Keenan, T. F., Law, B., Post, W. M., Ricciuto, D., Schaefer, K., Tian, H. Q., Tomelleri, E., Verbeeck, H., and Viovy, N.:. Evaluation of continental carbon cycle simulations with North American flux tower observations, Ecol. Monogr., 83, 531-556, 2013.

Randerson, J. T., Hoffman, F. M., Thornton, P. E., Mahowald, N. M., Lindsay, K., Lee, Y. H., Nevison, C. D., Doney, S. C., Bonan, G., Stoeckli, R., Covey, C., Running, S. W., and Fung, I. Y.: Systematic assessment of terrestrial biogeochemistry in coupled climate-carbon models, Glob. Change Biol., 15 2462-2484, 2009.

Ricciuto, D. M., King, A. W., Dragoni, D., and Post, W. M.: Parameter and prediction uncertainty in an optimized terrestrial carbon cycle model: Effects of constraining variables and data record length, J. Geophys. Res.-Biogeo., 116, G01033, doi:10.1029/2010JG001400, 2011.

Richardson, A. D., Williams, M., Hollinger, D., Moore, D., Dail, D., Davidson, E., Scott, N., Evans, R., Hughes, H., Lee, J., Rodrigues, C., and Savage, K.: Estimating parameters of a forest 
ecosystem $\mathrm{C}$ model with measurements of stocks and fluxes as joint constraints, Oecologia, 164, 25-40, 2010.

Richardson, A. D., Anderson, R. S., Arain, M. A., Barr, A. G., Bohrer, G., Chen, G. S., Chen, J. M., Ciais, P., Davis, K. J., Desai, A. R., Dietze, M. C., Dragoni, D., Garrity, S. R., Gough, C. M., Grant, R., Hollinger, D. Y., Margolis, H. A., McCaughey, H., Migliavacca, M., Monson, R. K., Munger, J. W., Poulter, B., Raczka, B. M., Ricciuto, D. M., Sahoo, A. K., Schaefer, K., Tian, H. Q., Vargas, R., Verbeeck, H., Xiao, J. F., and Xue, Y. K.: Terrestrial biosphere models need better representation of vegetation phenology: results from the North American Carbon Program Site Synthesis, Glob. Change Biol., 18, 566-584, 2012.

Richardson, A. D., Carbone, M. S., Keenan, T. F., Czimczik, C. I., Hollinger, D. Y., Murakami, P., Schaberg, P. G., and Xu, X. M.: Seasonal dynamics and age of stemwood nonstructural carbohydrates in temperate forest trees, New Phytol., 197, 850-861, 2013.

Riley, W. J., Subin, Z. M., Lawrence, D. M., Swenson, S. C., Torn, M. S., Meng, L., Mahowald, N. M., and Hess, P.: Barriers to predicting changes in global terrestrial methane fluxes: analyses using CLM4Me, a methane biogeochemistry model integrated in CESM, Biogeosciences, 8, 1925-1953, doi:10.5194/bg-8-19252011, 2011.

Runarsson, T. P. and Yao, X.: Stochastic ranking for constrained evolutionary optimization, IEEE T. Evolut. Comput., 4., 284294, 2000.

Sacks, W. J., Schimel, D. S., Monson, R. K., and Braswell, B. H.: Model-data synthesis of diurnal and seasonal $\mathrm{CO}_{2}$ fluxes at Niwot Ridge, Colorado, Glob. Change Biol., 12, 240-259, doi:10.1111/j.1365-2486.2005.01059.x, 2006.

Sargsyan, K., Safta, C., Habib, N. N., Debusschere, B. J., Ricciuto, D., and Thornton, P. E.: Dimensionality reduction for complex models via bayesian compressive sensing, Int. J. Uncertain. Quant., 4, 63-93, 2013.

Schaefer, K., Schwalm, C. R., Williams, C., Arain, M. A., Barr, A., Chen, J. M., Davis, K. J., Dimitrov, D., Hilton, T. W., Hollinger, D. Y., Humphreys, E., Poulter, B., Raczka, B. M., Richardson, A. D., Sahoo, A., Thornton, P. E., Vargas, R., Verbeeck, H., Anderson, R., Baker, I., Black T. A., Bolstad, P., Chen, J. Q., Curtis, P. S., Desai, A. R., Dietze, M., Dragoni, D., Gough, C., Grant, R. F., Gu, L. H., Jain, A., Kucharik, C., Law, B., Liu, S. G., Lokipitiya, E., Margolis, H. A., Matamala, R., McCaughey, J. H., Monson, R., Munger, J. W., Oechel, W., Peng, C. H., Price, D. T., Ricciuto, D., Riley, W. J., Roulet, N., Tian, H. Q. Tonitto, C., Torn, M., Weng, E. S., and Zhou, X. L.: A model-data comparison of gross primary productivity: Results from the North American Carbon Program site synthesis, J. Geophys. Res.-Biogeo., 117, G03010, doi:10.1029/2012JG001960, 2012.

Schimel, D. S., House, J. I., Hibbard, K. A., Bousquet, P., Ciais, P., Peylin, P., Braswell, B. H., Apps, M. J., Baker, D., Bondeau, A., Canadell, J., Churkina, G., Cramer, W., Denning, A. S., Field, C. B. Friendlingstein, P., Goodale, C., Heimann, M., Houghton, R. A., Melillo, J. M., Moore, B., Murdiyarso, D., Noble, I., Pacala, S. W., Prentice, I. C., Raupach, M. R., Rayner, P. J., Scholes, R. J., Steffen, W. L., and Wirth, C.: Recent patterns and mechanisms of carbon exchange by terrestrial ecosystems, Nature, 414, 169$172,2001$.

Schwalm, C. R., Williams, C. A., Schaefer, K., Anderson, R., Arain, M. A., Baker, I., Barr, A., Black, T. A., Chen, G. S., Chen, J. M.,
Ciais, P., Davis, K. J., Desai, A., Dietze, M., Dragoni, D., Fischer, M. L., Flanagan, L. B., Grant, R., Gu, L. H., Hollinger, D., Izaurralde, R. C., Kucharik, C., Lafleur, P., Law, B. E., Li, L. H., Li, Z. P., Liu, S. G., Lokupitiya, E., Luo, Y. Q., Ma, S. Y., Margolis, H., Matamala, R., McCaughey, H., Monson, R. K., Oechel, W. C., Peng, C. H., Poulter, B., Price, D. T., Ricciuto, D. M., Riley, W., Sahoo, A. K., Sprintsin, M., Sun, J. F., Tian, H. Q., Tonitto, C., Verbeeck, H. and Verma, S. B.: A model-data intercomparison of $\mathrm{CO}_{2}$ exchange across North America: Results from the North American Carbon Program site synthesis, J. Geophys. Res.-Biogeo., 115, G00H05, doi:10.1029/2009JG001229, 2010.

Shi, X., Mao, J., Thornton, P. E., Hoffman, F. M., and Post, W. M.: The impact of climate, $\mathrm{CO}_{2}$, nitrogen deposition and land use change on simulated contemporary global river flow, Geophys. Res. Lett., 38, L08704, doi:10.1029/2011GL046773, 2011.

Shi, X., Thornton, P. E., Ricciuto, D. M., Hanson, P. J., Mao, J., Sebestyen, S. D., Griffiths, N. A., and Bisht, G.: Representing northern peatland microtopography and hydrology within the Community Land Model, Biogeosciences, 12, 6463-6477, doi:10.5194/bg-12-6463-2015, 2015.

Shi, X., Mao, J., Thornton, P. E., and Huang, M. Y.: Spatiotemporal patterns of evapotranspiration in response to multiple environmental factors simulated by the Community Land Model, Environ. Res. Lett., 8, 024012, doi:10.1088/1748-9326/8/2/024012, 2013.

Stoy, P. C., Dietze, M. C., Richardson, A. D., Vargas, R., Barr, A. G., Anderson, R. S., Arain, M. A., Baker, I. T., Black, T. A., Chen, J. M., Cook, R. B., Gough, C. M., Grant, R. F., Hollinger, D. Y., Izaurralde, R. C., Kucharik, C. J., Lafleur, P., Law, B. E., Liu, S., Lokupitiya, E., Luo, Y., Munger, J. W., Peng, C., Poulter, B., Price, D. T., Ricciuto, D. M., Riley, W. J., Sahoo, A. K., Schaefer, K., Schwalm, C. R., Tian, H., Verbeeck, H., and Weng, E.: Evaluating the agreement between measurements and models of net ecosystem exchange at different times and timescales using wavelet coherence: an example using data from the North American Carbon Program Site-Level Interim Synthesis, Biogeosciences, 10, 6893-6909, doi:10.5194/bg-10-68932013, 2013.

Taylor, K. E., Stouffer, R. J., and Meehl, G. A.: An Overview of CMIP5 and the Experiment Design, B. Am. Meteorol. Soc., 93, 485-498, 2012.

Thornton, P. E. and Rosenbloom, N. A.: Ecosystem model spin-up: Estimating steady state conditions in a coupled terrestrial carbon and nitrogen cycle model, Ecol. Model., 189, 25-48, 2005.

Thornton, P. E., Lamarque, J. F., Rosenbloom, N. A., and Mahowald, N. M.: Influence of carbon-nitrogen cycle coupling on land model response to $\mathrm{CO}_{2}$ fertilization and climate variability, Global Biogeochem. Cy., 21, GB4018, doi:10.1029/2006GB002868, 2007.

Tissue, D. T., Thomas, R. B., and Strain, B. R.: Growth and photosynthesis of loblolly pine (Pinus taeda) after exposure to elevated $\mathrm{CO}_{2}$ for 19 months in the field, Tree Physiol., 16, 49-59, 1995.

Vandegehuchte, M. W., Guyot, A., Hubeau, M., De Swaef, T., Lockington, D. A., and Steppe, K.: Modelling reveals endogenous osmotic adaptation of storage tissue water potential as an important driver determining different stem diameter variation patterns in the mangrove species Avicennia marina and Rhizophora stylosa, Ann. Bot., 114, 667-676, doi:10.1093/aob/mct311, 2014. 
Vanlear, D. H., Taras, M. A., Waide, J. B., and Augspurger, M. $\mathrm{K}$.: Comparison of biomass equations for planted vs. natural loblolly-pine stands of sawtimber size, Forest Ecol. Manag., 14, 205-210, 1986.

Walker, A. P., Hanson, P. J., De Kauwe, M. G., Medlyn, B. E., Zaehle, S., Asao, S., Dietze, M., Hickler, T., Huntingford, C., Iversen, C. M., Jain, A., Lomas, M., Luo, Y., McCarthy, H., Parton, W. J., Prentice, I. C., Thornton, P. E., Wang, S., Wang, Y.-P., Warlind, D., Weng, E., Warren, J. M., Woodward, F. I., Oren, R., and Norby, R. J.: Comprehensive ecosystem model-data synthesis using multiple data sets at two temperate forest free-air $\mathrm{CO}_{2}$ enrichment experiments: Model performance at ambient $\mathrm{CO}_{2}$ concentration, J. Geophys. Res. Biogeosci., 119, 937-964, 2014.

Wang, D. L., Xu, Y., Thornton, P. E., King, A., Steed, C., Gu, L. H., and Schuchart, J.: A functional test platform for the Community Land Model, Environ. Modell. Softw., 55, 25-31, 2014.

Wang, Y. P., Kowalczyk, E., Leuning, R., Abramowitz, G., Raupach, M. R., Pak, B., van Gorsel, E., and Luhar, A.: Diagnosing errors in a land surface model (CABLE) in the time and frequency domains, J. Geophys. Res.-Biogeo., 116, G01034, doi:10.1029/2010JG001385, 2011.

Warren, J. M., Norby, R. J., and Wullschleger, S. D.: Elevated $\mathrm{CO}_{2}$ enhances leaf senescence during extreme drought in a temperate forest, Tree Physiol., 31, 117-130, 2011.

Warren, J. M., Iversen, C. M., Garten, C. T., Norby, R. J., Childs, J., Brice, D., Evans, R. M., Gu, L., Thornton, P. E., and Weston, D. J.: Timing and magnitude of $\mathrm{C}$ partitioning through a young loblolly pine (Pinus taeda L.) stand using C-13 labeling and shade treatments, Tree Physiol., 32, 799-813, 2012.
Warren, J. M., Iversen, C. M., Garten Jr., C. T., Norby, R. J., Childs, J., Brice, D., Evans, R. M., Gu, L., Thornton, P. E., and Weston, D. J.: PiTS-1: Carbon partitioning in loblolly pine after ${ }^{13} \mathrm{C}$ labeling and shade treatments, Carbon Dioxide Information Analysis Center, Oak Ridge National Laboratory, U.S. Department of Energy, Oak Ridge, Tennessee, USA doi:10.3334/CDIAC/ornlsfa.001, 2013.

White, M. A., Thornton, P. E., Running, S. W., and Nemani, R. R.: Parameterization and sensitivity analysis of the BIOME-BGC terrestrial ecosystem model: net primary production controls, Earth Interact., 4, 1-85, 2000.

Williams, M., Richardson, A. D., Reichstein, M., Stoy, P. C., Peylin, P., Verbeeck, H., Carvalhais, N., Jung, M., Hollinger, D. Y., Kattge, J., Leuning, R., Luo, Y., Tomelleri, E., Trudinger, C. M., and Wang, Y.-P.: Improving land surface models with FLUXNET data, Biogeosciences, 6, 1341-1359, doi:10.5194/bg-6-13412009, 2009.

Wullschleger, S. D., Hanson, P. J., and Todd, D. E.:Transpiration from a multi-species deciduous forest as estimated by xylem sap flow techniques, Forest Ecol. Manag., 143, 205-213, 2001.

Zaehle, S., Medlyn, B. E., De Kauwe, M. G., Walker, A. P., Dietze, M. C., Hickler, T., Luo, Y. Q., Wang, Y. P., El-Masri, B., Thornton, P., Jain, A., Wang, S. S., Warlind, D., Weng, W. S., Parton, W., Iversen, C. M., Gallet-Budynek, A., McCarthy, H., Finzi, A. C., Hanson, P. J., Prentice, I. C., Oren, R., and Norby, R. J.: Evaluation of 11 terrestrial carbon-nitrogen cycle models against observations from two temperate Free-Air $\mathrm{CO}_{2}$ Enrichment studies, New Phytol., 202, 803-822, 2014. 